Historic, archived document

Do not assume content reflects current scientific knowledge, policies, or practices. 



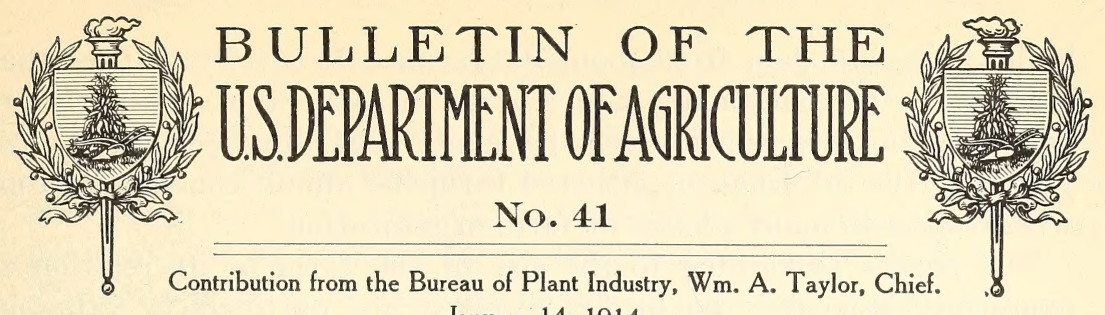
January 14, 1914.

\section{A FARM-MANAGEMENT SURVEY OF THREE REP- RESENTATIVE AREAS IN INDIANA, ILLINOIS, AND IOWA. ${ }^{1}$}

By E. H. Тномson, Agriculturist, and H. M. Dixon, Scientific Assistant, Office of Farm Management.

\section{INTRODUCTION. ${ }^{1}$}

Farm management treats of the business of farming. A farmmanagement survey has for its purpose a study of the profits of the individual farmer to determine the factors that control his income. Agriculture to be progressive must be profitable. As farming is a business involving both capital and labor, the farmer should receive a fair income on his investment as well as wages for his labor. Many farmers receive no wages for their work, due largely to poor farm organization or from following types of agriculture unsuited to their particular region.

Successful farming is an individual, economic problem. The farm is a combination of enterprises, and their individual organization will determine in a in re measure its profitableness.

The corn-belt States excel almost all other regions in wealth of farm products. On rich soil with ample rainfall a system of agriculture is found that is unequaled as an example of the expansive type of farming. This type is developed on the basis of the farm work horse as the means of motive power. To attain its highest efficiency, this type calls for expansion in farming area. Such a type is in direct contrast to the agriculture of the countries of southern Europe or of Belgium, where man and not the horse furnishes the labor. The American type is based on the product per man, the European on the product per acre of land.

In the summer of 1911 the Office of Farm Management of the Bureau of Plant Industry, United States Department of Agriculture, made a farm-management survey of certain districts in Indiana, Illinois, and Iowa. The results of this survey, which are outlined in this

Acknowledgment is due to Messrs. H. F. Williams, E. L. Currier, E. M. McGrew, O. S. Rayner, and C. Wensel, who assisted in collecting the data presented in this bulletin. Thanks are also extended to the many farmers in the regions studied through whose courtesy this work was made possible.

$13131^{\circ}-14-1$ 
bulletin, include data from about 700 farms. It is fully realized that further studies, embracing larger areas in each State, are necessary before definite statements can be made regarding certain points. However, the information gathered furnishes almost conclusive proof with respect to many phases of farm organization.

The results pertaining to the size of the farm in its relation to operating costs and the profits received are particularly valuable. It would be highly desirable to make a survey of the same regions for several successive years. If such data were obtained, however, it is believed that the conclusions would be the same as those from the one year's study. A possible exception might be the conclusions relative to the best paying type of farming. Extreme fluctuation in prices may make some crops unprofitable at certain times. Potatoes and peaches are two excellent illustrations of this.

Checking the results of any one year with the average prices for a period of years permits fairly accurate conclusions. Investigations made in different years and in widely separated States all point to the same general principles that apparently control a successful fárm.

\section{METHOD OF WORK.}

The data presented were obtained by having trained investigators who were thoroughly familiar with the agriculture in each district personally visit the farmers. Every farmer in the area selected for study was interviewed and a record of the year's business obtained. In this way, by including all the farms in a certain area, average results were secured.

Experience has proved that one can not select farms which represent the average of a community. Good farm buildings and neatly kept fences are not always sure signs of profitable farming.

Certain questions are difficult for the farmer to answer and in a few instances his answer may be considerably in error. This trouble is eliminated by the fact that some men will underestimate, while others will overestimate the facts. The average is approximately correct. Only those results are included where there is a sufficient number of instances to insure reasonable accuracy.

The farmer knows more about his business than most people give him credit for. Even though he keeps no records he is capable of giving a very close estimate on all those things with which he is familiar.

Farm data gathered by the survey method of study ${ }^{1}$ are unquestionably as accurate as need be for all practical purposes.

${ }_{1}$ Warren, G. F., Livermore, K. C., and others. An agricultural survey-townships of Ithaca, Dryden, Danby, and Lansing, Tompkins County, New York. New York Cornell Agricultural Experiment Station, Bulletin 295, pp. 375-569, figs. 147-201, 1911.

Thomson, E. H. Agricultural survey of four townships in southern New Hampshire. U. S. Department of Agriculture, Bureau of Plant Industry, Circular 75, 19 pp., 3 figs., 1911. 


\section{LOCATION AND DESCRIPTION OF THE AREAS STUDIED.}

Three districts, one each in Indiana, Illinois, and Iowa, were selected for the farm-management study, the approximate location of each being shown in figure 1 . In choosing these areas an effort was made to have as uniform farm conditions as possible in each region. The soil and type of farming have a decided bearing on the profitableness of agriculture in a region. These factors were carefully considered. Owing to differences in land values and to the general system of farming it was not possible to secure three areas in separate States that would be similar in all respects. The aim was to have each district representative of the agricultural conditions prevailing over a large area.

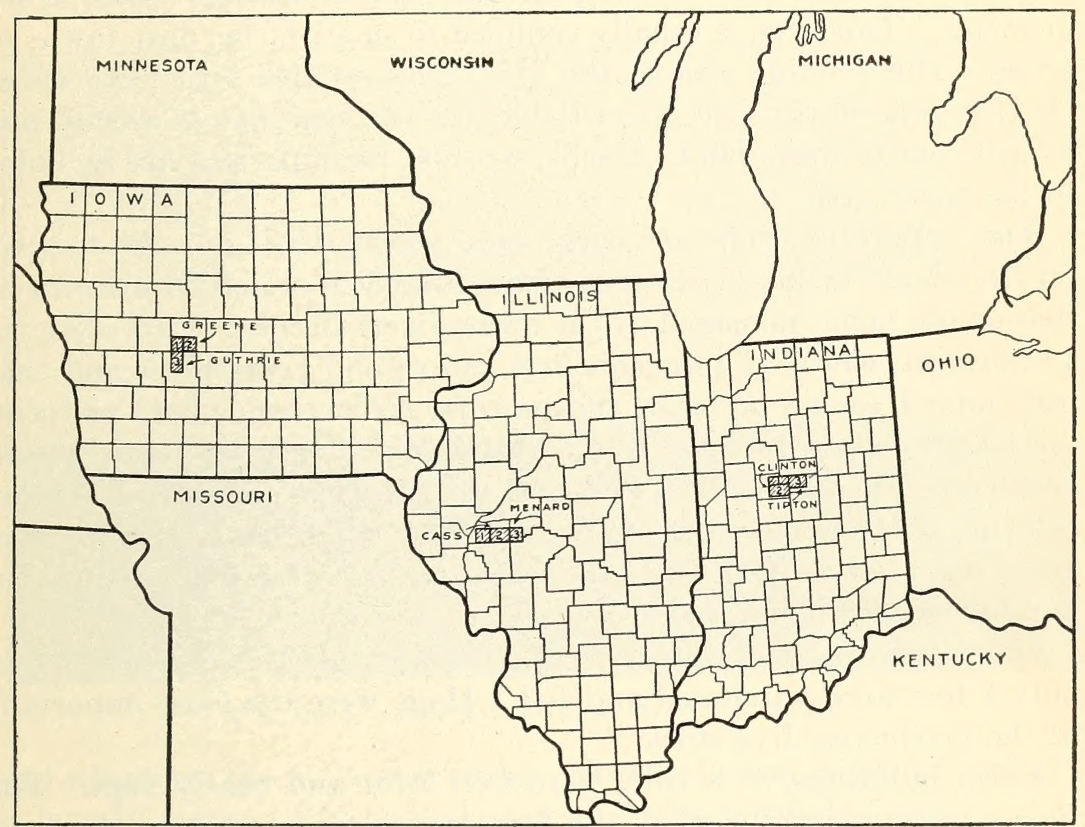

F'IG. 1.-Map of Iowa, Illinois, and Indiana, showing the location of the areas studied.

Corn, oats, wheat, and hay were the crops universally grown in the districts studied, corn being the predominating crop in all of the districts. Hogs and cattle, with a few sheep, constituted the productive live stock.

\section{DESCRIPTION OF THE INDIANA AREA.}

In Indiana three adjoining townships-Forest, Johnson, and Prairie-were selected. This region is in Clinton and Tipton counties, about 40 miles north of Indianapolis. The nearest city of considerable size is Frankfort. Practically all of the farm produce sold 
was shipped out of the counties, there being no local market of any consequence.

This area is one of the oldest settled regions in the central part of the State. The land was originally covered with heavy hardwood timber, except for a few strips locally known as prairie soil. The land is level to slightly rolling, being cut up in some places by sluggish streams. The soil is a dark, rich loam and under good management is very productive. After the land was cleared large areas were too wet to cultivate well, but extensive systems of tile drainage have overcome this difficulty. Many farms have miles of tile drains running through them.

General farming is followed in almost all cases. In a few sections canning factories have developed, and this encourages some truck growing. This type is usually confined to small farms near towns or cities. The average size of the 277 farms studied was 112.8 acres. Of this area 86 per cent was tillable, 9.2 per cent was in woods, and 4.5 per cent in waste land. Roads, streams, swamps, etc., are included in the waste area.

The important crops are corn, oats, wheat, hay, and clover seed. Of the rented farms 38 per cent of the tillable area and 36 per cent of that on the farms managed by the owners were in corn. Oats occupied 19 per cent, wheat 11 per cent, first and second year clover and timothy mixed, each 8 per cent, and pasture, not permanent, 13 per cent.

The prevailing rotation was corn two or three years, oats, wheat, clover and timothy mixed, and pasture. Few men follow a definite rotation on their entire farm, certain fields often being kept in corn for several years. Generally the corn and hay were fed, oats, wheat, and clover seed being the crops sold.

On the farms studied practically no beef cattle were raised and only a few were purchased and fed. Hogs were the most important of the productive live stock.

Farm buildings, as a rule, were well built and neatly kept. The fences were unusually good, the farmers seeming to take a pride in this method of farm improvement.

Practically all the roads in this region were graveled, there being only a few of the original dirt roads, which are almost impassable in the early spring. The building of the graveled roads has been a heavy expense to these farming districts and has been one of the causes of high taxes. The region as a whole is more prosperous and enterprising than some other sections of the State.

DESCRIPTION OF THE ILLINOIS AREA.

In Illinois the district selected comprised an area of approximately 110 square miles in the southern part of Cass and Menard 
Counties. Among others it included the townships of Virginia, Ashland, and Tallula. By railroad the area is about 200 miles from Chicago and 100 miles from St. Louis. All of the produce sold is shipped out of the district.

The land, except along the streams, is prairie soil. It is a sticky black loam, common to large areas in the central part of the State. Figure 2 shows the general character of the country. It lies very level in places and is likely to be wet unless tile-drained. Nearly all farms have excellent systems of tile drainage, which have rendered the soil one of the most productive in America. The continuous cropping of corn for over 50 years, although having its effect, is almost unnoticeable. With any reasonable regard to the conservation of fertility, this soil would seem almost inexhaustible. Corn, oats,

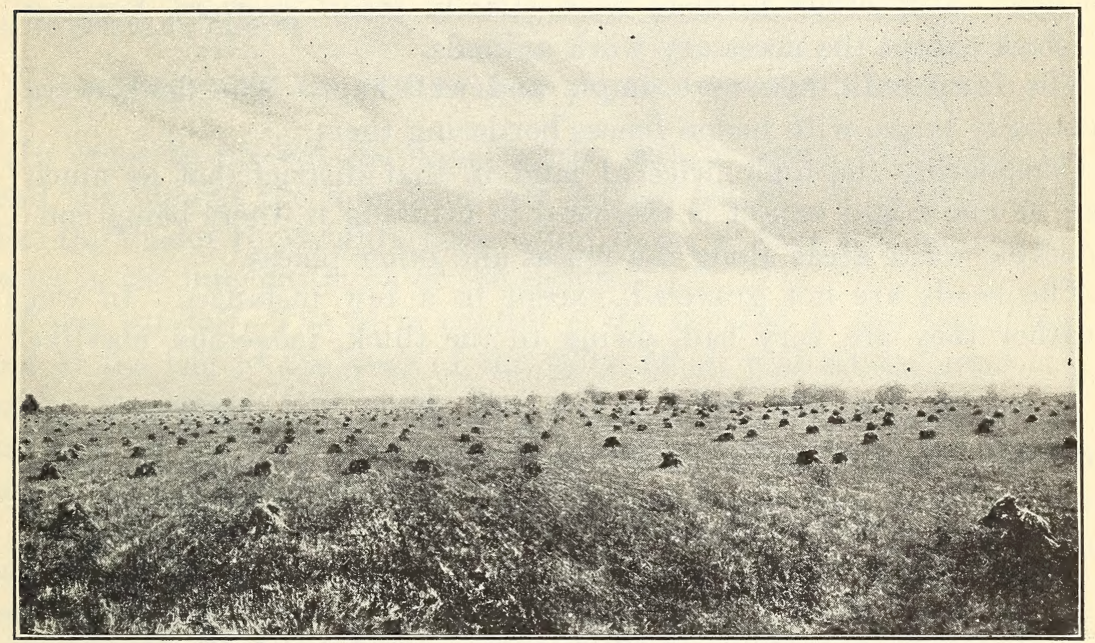

Fig. 2.-A typical harvest scene in central Illinois.

and wheat are the important crops. Very little hay is grown, and this is largely clover. The second crop of clover is cut for seed.

The average size of the 196 farms studied was 240 acres. Of this 95 per cent is tillable, 3 per cent is in woods, and 2 per cent in waste land.

The area in corn per farm was 97 acres, the proportion on the tenant farms being about 10 per cent greater than on the farms operated by owners. Oats occupied 34 acres and wheat the same. The area in hay was small, being only 13 acres on the owners' farms and 7 acres on those rented. The area in permanent pasture was greater than that in wheat, except on the tenant farms, where it constituted one-half as much. 
The rotation followed by a few men was corn three years, oats, and wheat. Clover seed was sown in the wheat. This generally makes a good growth the same year, after the wheat is cut. It was usually plowed under the same fall or the following spring on these farms and was not allowed to grow a crop of hay. Several farms had fields where corn had been grown almost continuously for a number of years.

The plan generally followed was to plant as much corn as could be taken care of during the rush season. Other crops, such as wheat and oats, were used to fill in. Oats are generally recognized as being an unprofitable crop on such high-priced land.

A large number of live stock was kept on some farms. The feeding of cattle, hogs, mules, and horses gave an important source of income. Still other farmers were strictly grain growers, keeping no stock except the necessary work animals.

The farm buildings were ample and well kept. The fields were unusually large, with hedge fences bordering them.

Considering the high price of land in that district, not as much care as one might expect is exercised in utilizing it, there being considerable waste areas along the fences and other places.

The roads are not graveled, except in a few instances. In wet weather they are very bad, owing to the thick, tenacious, claylike soil.

The farmers in the area studied are thrifty and are hard workers. They know how to utilize machinery effectively so as to handle large areas, one man and team being expected to take care of 60 acres of corn.

\section{DESCRIPTION OF THE IOWA AREA.}

In Iowa the townships of Willow, Greenbrier, and Highland, in the counties of Guthrie and Greene, were selected. This area is about 50 miles northwest of Des Moines and on the Chicago and Omaha line of the Chicago, Milwaukee, \& St. Paul Railroad.

The region has not been settled as long as either the one in Illinois or that in Indiana. Being prairie land with timber growth only along the streams, it is a fertile and productive agricultural district. In some places it is very rolling, steep hills being not uncommon. The rough areas are confined to the southern part, particularly to Guthrie County.

The soil is a dark, rich loam and is very poorly drained in the more level areas. Tile-drainage projects have opened up thousands of acres in that vicinity within the last few years.

Corn, oats, and hay are the main crops. Wheat is sown, but not extensively. 
The average size of the 227 farms studied was 186 acres. Of this area 91 per cent was tillable. Approximately one-half of the crop land was in corn, the other half being in oats and hay. Nearly 30 per cent of the tillable area was used for pasture.

The rotation that was often followed was corn (two to three years), oats, clover and timothy hay.

Beef cattle and hogs constitute the most important part of the farm business. Large numbers of western steers are purchased and fed, while in the hilly sections, distant from a railroad, a few cattle are raised.

The selling of corn is generally confined to the farms on the level lowlands and near the stations. Many of the farms are far from market and, although the roads are fairly good, transportation is an important factor.

\section{DEFINITIONS OF TERMS USED IN THIS SURVEY REPORT.}

In order to present the data clearly, certain terms which will be used throughout the discussion are defined below. It is important that the reader thoroughly understand these, as they will materially assist in the interpretation of the results.

Farm capital.-The farm capital is the average at the beginning and at the end of the year of the value of all real estate, improvements, machinery, live stock, feed and supplies, and cash necessary to carry on the farm business. It includes the value of the farmhouse, but not the household furnishings.

Receipts.-The farm receipts include the amount received from the sale of all farm products and also the receipts from outside labor, rent of buildings, etc. If the value of buildings, stock, produce, or equipment is greater at the end of the year than at the beginning, the difference is considered a receipt.

Expenses.-The farm expenses represent the amount of money paid out during the year to carry on the farm business. If the value of buildings, stock, produce, or equipment at the end of the year is less than at the beginning, this loss is considered an expense. Household or personal expenses are not included, except the value of board furnished to hired help.

F arm income.-The farm income is the difference between the receipts and expenses. It represents the amount of money available for the farmer's living, provided he has no interest to pay on mortgages or other debts.

Labor income.-The labor income is the amount that the farm operator has left for his labor after 5 per cent interest on the average capital is deducted from the farm income. It represents what he earned as a result of his year's labor after the earning power of his capital 
has been deducted. In addition to the labor income the operator received a house to live in, fuel (when cut from the farm), garden products, milk, butter, eggs, etc. The labor income corresponds to what a hired man receives when he is given so much cash wages, together with board and room.

Farm owner.-The term "farm owner" is applied to the man who works or manages the farm he owns.

Owner additional.-The term "owner additional " is used to designate the man who owns a farm and rents additional land.

Landlord.-The landlord is the owner of a farm which is rented to a tenant.

Tenant.-The tenant is the person operating a farm rented from one landlord.

Tenant additional.-The term "tenant additional" applies to the person operating land rented from more than one landlord.

Number and kinds of farms studied.-In the total area studied in the three States 700 complete farm records were secured. These were divided into four classes, according to the method of management. The farms operated by owners numbered 273. None of these men rented additional land, but worked only the farms they owned. The farms operated by tenants numbered 247 , each farm being owned by one landlord, whose income from that farm was determined. The third class comprised a group of farmers, 126 in all, who owned one farm and rented additional land. They took this means of having the use of more land than they actually owned. The fourth class, 51 in number, is made up of a few tenants who rented land from two or more landlords. These were not included in the tabulations with the other tenant farmers who operated only one farm.

Of the 700 farms studied, 57 per cent were operated by owners and 43 per cent by tenants. Table I gives the number and classification of the records taken in each of the States.

TABLE I.-Number and classification of farms studied in Indiana, Illinois, and Iouca.

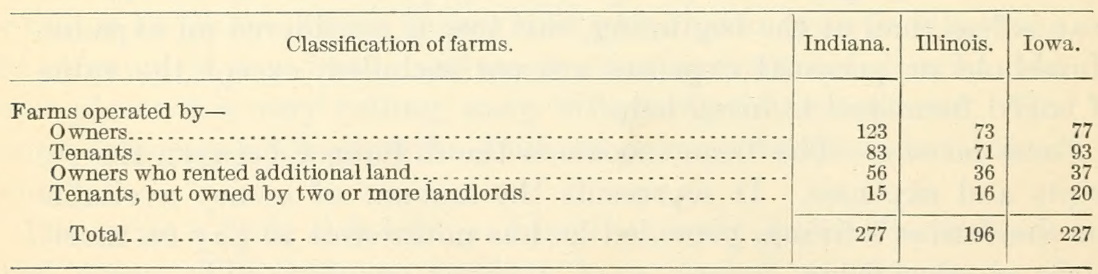

\section{INFLUENCE OF CLIMATE ON RESULTS.}

In studying the profits of a region certain factors which may exert a marked influence must be noted. It has been conclusively demon- 
strated that the rainfall during the months of July and August determines to a large extent the yield of corn.

Figure 3 shows the average monthly rainfall for 10 years, as well as for the year 1910 .

In Illinois and Indiana the year may be said to be normal in almost all climatic respects. In Iowa a drought in early summer caused a shortage in the returns of possibly 20 per cent below normal. The effects of this drought were most noticeable on the corn crop. The prices of live stock and grain are discussed on page 31 . These had a marked effect on the profits
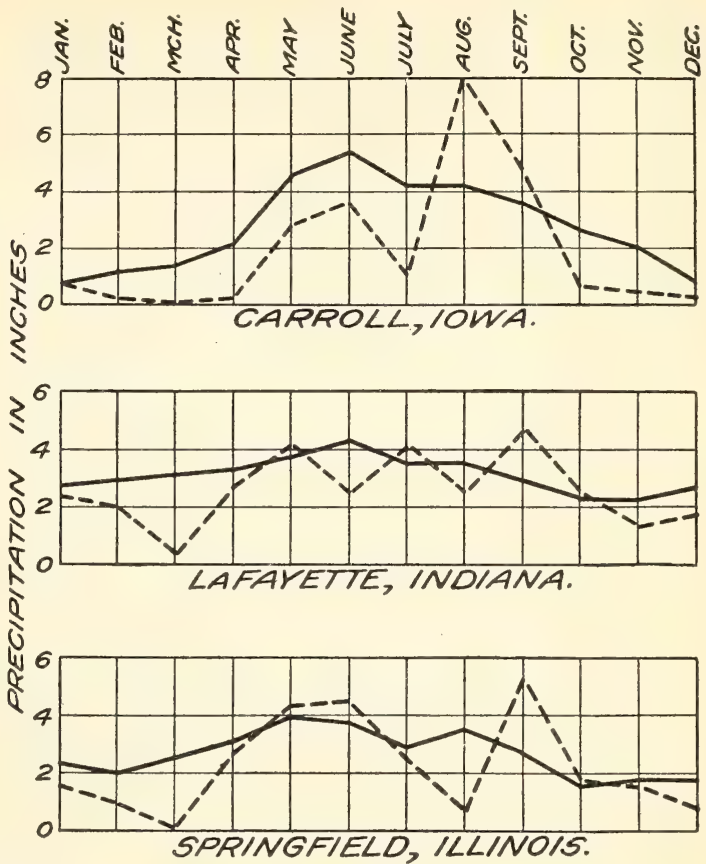

\section{- AVERAGE MONTHLY PRECIPITATION,1901-1910 INCLUSIVE.} - MONTHLY PRECIPITATION, 1910

Fig. 3.-Chart showing a comparison of the rainfall in 1910 with the 10-year average for each district surveyed. derived from the two types of farming.

FARM PROFITS.

\section{INCOMES RECEIVED BY FARM OWNERS.}

The average capital, receipts, expenditures, and labor incomes for the 273 farms operated by owners are given in Table II.

TABLE II.-Average area, capital, receipts, expenses, and profits on 273 farms operated by owners in Indiana, Illinois, and Iowa.

Item. $\ldots \ldots \ldots$

1 The value of unpaid family labor, except the operator's, has been added in with the other farm expenses. It is equivalent to the amount that would have been paid to hired help had not the family done the work. The average amount per farm was $\$ 86$ in Indiana, $\$ 127$ in Illinois, and $\$ 101$ in Iowa. 
The average capital per farm is $\$ 17,535$ in Indiana and nearly three times that amount in Illinois. This difference is due to much larger farms and higher value of land per acre in the latter State.

The receipts per farm in all three regions approximate one-tenth of the capital invested.

The farm income, which represents the income earned by the combined forces of labor and capital, is the amount available to the farmer for his living and savings, provided he had no interest to pay on any mortgage or other debt.

Deducting 5 per cent interest on the average capital leaves an average labor income of $\$ 408$ for the 273 farm owners. This income, in addition to the food products furnished by the farm, represents the farmer's salary as manager of the business. It is evident that these men are receiving only a moderate sum for their year's work. If they sold their farms at inventory value and invested the money in good securities at $\check{5}$ per cent the interest alone on a capital of $\$ 30,600$ would return them $\$ 1,530$. In addition to this, they would have the amount they were able to earn at other work.

The assertion that farmers are making large profits is erroneous. They are living on the earnings of their investment and not on the real profits of the farm. A farmer having an investment of $\$ 20,000$, with no mortgage, may receive a minus labor income, yet have nearly $\$ 1,000$ as interest on which to live. It is assumed in this discussion that capital should return 5 per cent before allowing the farmer anything for his labor.

VARIATION IN THE LABOR INCOMES OF OWNERS.

In Table III the farms are divided according to the labor income received. Each group gives the number of men who made labor incomes ranging from minus $\$ 500$ and more to over $\$ 5,000$.

TABLE III.-Dariation in labor incomes on $2 \% 3$ farms operated by owners in Indiana, Illinois, and Iowa.

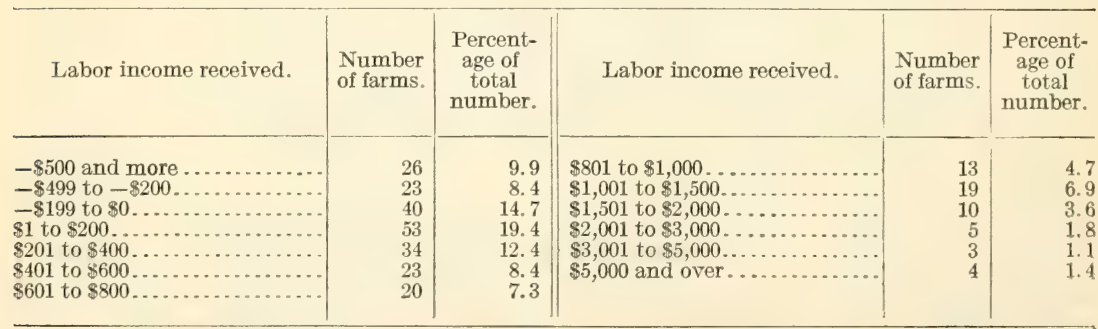

One farmer out of every 22 received a labor income of over $\$ 2.000$ a year. One farmer out of every three paid for the privilege of working his farm, that is, after deducting 5 per cent interest on bis investment he failed to make a plus labor income. 


\section{INCOMES RECEIVED BY FARM TENANTS.}

There are few regions in the United States where tenant farming has been developed so extensively and where it plays such an important part in agricultural production as in the corn belt. The percentage of farms worked by tenants is second only to those operated by owners, and the areas farmed and the products grown compare very favorably with those of the farm owners.

In the region covered by this survey, records were secured from 247 tenant farmers. These men rented one farm, or land owned by one person. There were 51 other tenants who rented farms from two different parties. Their records show the same results, which have not been included in Table IV.

TABI.E IV.-Average capital, receipts, expenses, and profits of tenants on $24 \%$ farms operated by tenants in Indiana, Illinois, and Iowa.

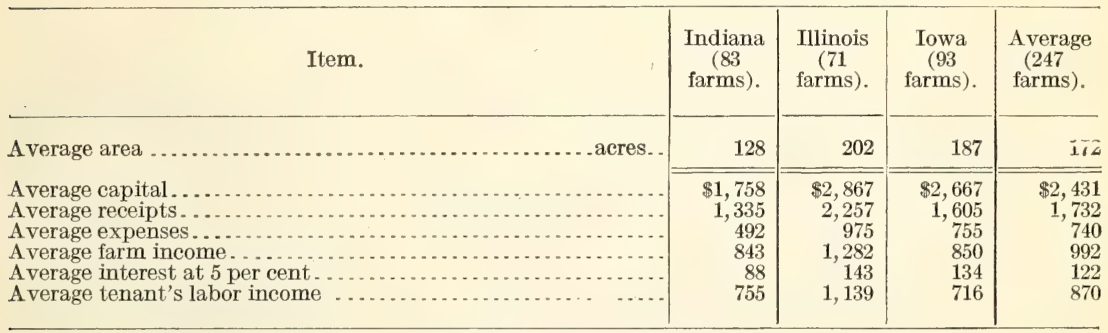

Most tenants hope to become farm owners as soon as they have sufficient capital. The income they receive while leasing a farm is a measure of the period they will have to work before making the change. The average tenant in Indiana, with an investment of $\$ 1,758$, received $\$ 755$ for his year's work. In Illinois, with an investment of $\$ 2,86 \tau$, he received $\$ 1,139$ as a labor income. In Iowa, with an average capital of $\$ 2,667$, his labor income was $\$ 716$. Owing to drought in early summer, the income of the tenant in Iowa was probably 20 per cent less than it would have been in a normal crop year.

The 247 tenant farmers made an average labor income of $\$ 870$ from an investment of less than $\$ 2,500$. When it is remembered that the farm owners with over 12 times this investment made less than half the labor income of the tenants, the evidence is unmistakable that the man with small capital should rent rather than buy a farm.

For the amount invested, the tenant's income is very much greater than that of the farm owner. The sum available for the family living, however, is smaller in the case of the tenant, for the farm owner, with an average capital of $\$ 30,606$ ( see Table II), has $\$ 1,530$ interest to use, as well as the $\$ 408$ labor income. Thus, if the farm owner is free of debt, as one-half of them are, he has $\$ 1,938$ available for a living, as compared with the tenant's $\$ 992$. 
In addition to this sum available for a living. each has what the farm furnishes in the shape of produce. After the tenant pays his living and personal expenses out of this amount his sarings can not be large. If we allow the omners 3.5 per cent on their investment

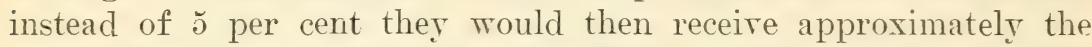
same labor income as the tenants $(\$ 8 \pi 0)$. This percentage is the same as that receired by the landlords from the rented farms. Taking into consideration the results from all the farms managed by owners and by tenants, they show that a return can be expected of 3.5 per cent on the investment and a labor income of $\$ 870$.

Seasonal rariation and fluctuating prices have a marked influence on the profits from farming in the districts studied. The arerage price received for corn sold by the landlords of the 247 tenant farms was 41 cents, and a drop of 5 cents alone would have reduced the income 6 per cent.

\section{INCOMES RECEIVED BY LANDLORDS.}

The farm. in the case of the landlord, is a business inrestment. He furnishes the capital, largely in the form of land, and the tenant furnishes the necessary labor and other means for its operation. The average investment of the 247 landlords for the three States studied was $\$ 25,210$. The arerage net income on the capital inrested was 3.5 per cent. All items of expense, including repairs, seeds, taxes, and insurance, were deducted before figuring the net returns. Table $T$ gives the arerage capital, receipts, expenses, and returns for the landlords in each State.

TABLE T.-Average capital, receipts, expenses. and profits of lanflords for $24 \%$ farms operated by tenants, as shown in Table IV.

\begin{tabular}{|c|c|c|c|c|}
\hline Item. & $\begin{array}{c}\text { Indiana } \\
\text { ( } 83 \\
\text { farms). }\end{array}$ & $\begin{array}{l}\text { Illinois } \\
\text { ( } 71 \\
\text { farms). }\end{array}$ & $\begin{array}{c}\text { Iowa } \\
\text { (93 } \\
\text { farms). }\end{array}$ & $\begin{array}{c}\text { A rerage } \\
\text { ( } 247 \\
\text { farms). }\end{array}$ \\
\hline 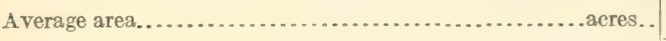 & 128 & 202 & 187 & 172 \\
\hline $\begin{array}{l}\text { A verage capital } \ldots \ldots \\
\text { A verage receipts } . \ldots \\
\text { A verage expenses } \ldots \ldots \\
\text { Average farm income } .\end{array}$ & $\begin{array}{r}\$ 18,423 \\
1,002 \\
351 \\
651\end{array}$ & $\begin{array}{r}\$ 36,479 \\
1,538 \\
213 \\
1,325\end{array}$ & $\begin{array}{r}\$ 20,728 \\
1,014 \\
354 \\
660\end{array}$ & $\begin{array}{r}\$ 25,210 \\
1,185 \\
306 \\
879\end{array}$ \\
\hline Average profit on investment $1 \ldots \ldots \ldots \ldots . . . .$. per cent. & 3.53 & 3.64 & 3.19 & 3.5 \\
\hline
\end{tabular}

I Obtained by dividing the farm income by the average capital.

The average return on investment from the farms in Illinois was 3.6 per cent, in Iowa 3.2 per cent, and in Indiana 3.5 per cent. The income is a moderate return on the large capital, considering the enormous rise in land values during the past 10 year's. In computing this income no crerlit has been allowed for the rise in value of real estate, except in case of actual improvements. 
There has been a marked tendency throughout the entire country to consider the farm more and more as a business proposition. The landlord who is receiving 3.5 per cent net from his farm, with the bare land figured at $\$ 150$ or more an acre, has a good, safe investment. It would seem from the results that if the year studied was a normal one, land in the corn belt is not overvalued. Changes in the price of the staple products, such as corn or oats, or material changes in the cost of production of these crops would be reflected in the price of farm land. Unless the price of corn becomes much higher for the next period of years, a pronounced increase in the value of land in this region can not be expected.

The advisability of buying a farm as an investment with the intention of not living on it is often a perplexing question.

VARIATION IN THE PROFITS OF IANDLORDS.

Table VI gives the variation in the landlords' returns in the three States studied.

TABLE VI.-Variation in profits of landlords on $2,4 \%$ tenant farms in Indiana, Illinois, and Iowa.

\begin{tabular}{|c|c|c|c|c|c|}
\hline $\begin{array}{l}\text { Landlord's profit on invest- } \\
\text { ment (per cent). }\end{array}$ & $\begin{array}{l}\text { Number } \\
\text { of land- } \\
\text { lords. }\end{array}$ & $\begin{array}{l}\text { Percent- } \\
\text { age } \\
\text { of total } \\
\text { number. }\end{array}$ & $\begin{array}{l}\text { Landiord's profit on invest- } \\
\text { ment (per cent). }\end{array}$ & $\begin{array}{l}\text { Number } \\
\text { of land- } \\
\text { lords. }\end{array}$ & $\begin{array}{l}\text { Percent- } \\
\text { age } \\
\text { of total } \\
\text { number. }\end{array}$ \\
\hline $\begin{array}{l}\text { Less } \operatorname{than} 1 \ldots \ldots \\
1.1 \text { to } 2 \ldots \\
2.1 \text { to } 3 . \ldots \ldots \\
3.1 \text { to } 4 \ldots \ldots\end{array}$ & $\begin{array}{r}6 \\
20 \\
75 \\
78\end{array}$ & $\begin{array}{r}2.4 \\
8.1 \\
30.4 \\
31.6\end{array}$ & $\begin{array}{l}4.1 \text { to } 5 \ldots \ldots \\
5.1 \text { to } 6 \text {. } \\
6.1 \text { to } 7 \text { } \\
7.1 \text { to } 8\end{array}$ & $\begin{array}{r}42 \\
13 \\
7 \\
6\end{array}$ & $\begin{array}{r}17.0 \\
5.3 \\
2.8 \\
2.4\end{array}$ \\
\hline
\end{tabular}

Out of 247 men 6 received less than 1 per cent on their investments. The same number received between 7 and 8 per cent; none received over 8 per cent. It is clear that no phenomenal returns can be expected from capital put in farm land in those States at the present time. It is believed that the data in Table VI are a very good indication of the returns one may expect from a farm investment in those districts. The chances of making more than 5 per cent are about 1 in 10.

\section{BANKERS' ESTIMATES OF FARM PROFITS.}

In the corn-belt States one is nearly always referred to the local banker for information concerning the farmers of the region. The banker is considered good authority on all questions relating to the farmer's business, his income, investment, etc. Inquiry relative to the incomes of the farmers was made of the cashiers of 90 banks in 
the regions studied. Fifty-three replies were received and the results are given in Table VII.

TABLE VII.-Bankers' estimates of farmer's profits compared with facts brought out by the survey.

\begin{tabular}{|c|c|c|c|c|}
\hline & \multicolumn{2}{|c|}{$\begin{array}{l}\text { Landlord's profit on } \\
\text { farm investment (per } \\
\text { cent). }\end{array}$} & \multicolumn{2}{|c|}{ Tenant's labor income. } \\
\hline & $\begin{array}{l}\text { Bankers' } \\
\text { estimate. }\end{array}$ & $\begin{array}{l}\text { Returns as } \\
\text { shown by } \\
\text { survey. }\end{array}$ & $\begin{array}{l}\text { Bankers' } \\
\text { estimate. }\end{array}$ & $\begin{array}{l}\text { Incomes as } \\
\text { shown by } \\
\text { survey. }\end{array}$ \\
\hline 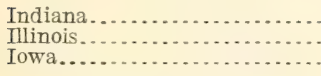 & $\begin{array}{l}4.20 \\
4.91 \\
4.06\end{array}$ & $\begin{array}{l}3.53 \\
3.64 \\
3.19\end{array}$ & $\begin{array}{r}\$ 625 \\
691 \\
656\end{array}$ & $\begin{array}{r}\$ 755 \\
1,139 \\
716\end{array}$ \\
\hline Average......... & 4.91 & 3.50 & 657 & 870 \\
\hline
\end{tabular}

These estimates, although not agreeing identically with the results as found by the survey, are exceedingly interesting. The bankers believed that the landlords mere getting about 1.4 per cent more than they were and the tenants \$213 less than they were. Thus, the bankers' estimates of the total income from the rented farms compares rery closely with the results of our investigations.

Inquiry was also made as to the interest that the farmers would receive if they sold their farms and placed their money in the bank. The average rate given is 3.7 per cent. This nearly corresponds with the returns that the landlords are actually receiving from their capital invested. It also agrees with the income of the farm owners, if we allow them the same labor income that the tenants receire.

The arerage value per acre of the land (including buildings) in the three States is approximately $\$ 145$ in Indiana, $\$ 175$ in Illinois, and $\$ 111$ in Iowa. The profits which are shown in the preceding tables are figured on this basis.

\section{INCOMES OF FARM OWNERS WHO RENT ADDITIONAL LAND.}

The stages that almost every farmer goes through in becoming a farm owner are, first, as a hired man; second, as a tenant; third, as an owner. In addition, there is another step that many men take in acquiring farms of sufficient size to gire them comfortable incomes. Many men are able to own a small farm but feel the need of having a larger area to mork. By renting additional land, usually parts of an adjoining farm, they utilize their labor and work horses to better adrantage and receive greater returns without any appreciable increase in investment. Table VIII gives the capital, receipts, expenses, and labor income for 129 farmers who are following this method. 
TABLE VIII.-Average capital, receipts, expenses, and profits on 129 farms operated by owners renting additional land.

\begin{tabular}{|c|c|c|c|c|}
\hline Item. & $\begin{array}{c}\text { Indiana } \\
(56 \\
\text { farms). }\end{array}$ & $\begin{array}{c}\text { Tllinois } \\
(36 \\
\text { farms). }\end{array}$ & $\begin{array}{c}\text { Iowa } \\
(37 \\
\text { farms). }\end{array}$ & $\begin{array}{c}\text { Average } \\
\text { (129 } \\
\text { farms). }\end{array}$ \\
\hline 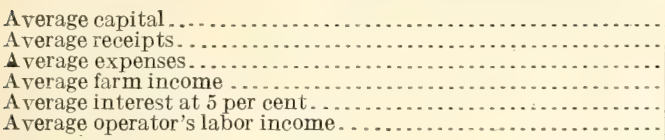 & $\begin{array}{r}\$ 11,321 \\
1,780 \\
742 \\
1,038 \\
566 \\
472\end{array}$ & $\begin{array}{r}\$ 32,382 \\
4,279 \\
1,599 \\
2,680 \\
1,619 \\
1,061\end{array}$ & $\begin{array}{r}\$ 17,829 \\
2,228 \\
887 \\
1,341 \\
891 \\
450\end{array}$ & $\begin{array}{r}\$ 20,510 \\
2,762 \\
1,076 \\
1,686 \\
1,025 \\
661\end{array}$ \\
\hline
\end{tabular}

With $\$ 10,000$ less invested than is shown by the owners operating only their own land, the labor income of these owners additional is over $\$ 250$ greater than that of the farm owners. The average size of the farm owned was 105 acres, and 78 acres additional were rented. Where it is possible, this method permits a farmer to have a home of his own and at the same time a good-sized farm business with a comparatively small investment. It is an intermediate step between tenant and owner.

\section{DISTRIBUTION OF FARM RECEIPTS.}

The farm receipts are derived mainly from crops and live stock. The proportion received from each varies with the method of operation as to whether run by owner or tenant, as well as with the type of farming followed. In Indiana 48 per cent of the total income received by the owners was from the sale of live stock, while the tenants received only 36 per cent from this source. In Illinois cattle and hogs were fed in much larger numbers, the income of the owners from live stock being 60 per cent of the total receipts. On the tenant farms 50 per cent of the receipts was from the sale of crops and 36 per cent from the sale of stock.

In Table IX the distribution of the receipts for both owners and tenants is given.

TABLE IX.-Distribution of farm receipts to landlord and tenant on 247 farms operated by owners and tenants in Indiana, Illinois, and Iowa.

\begin{tabular}{|c|c|c|c|c|c|c|c|c|}
\hline \multirow{3}{*}{ Source of income. } & \multirow{2}{*}{\multicolumn{2}{|c|}{$\begin{array}{l}\text { Operated by own- } \\
\text { ers ( } 273 \text { farms). }\end{array}$}} & \multicolumn{6}{|c|}{ Operated by tenants (247 farms). } \\
\hline & & & \multicolumn{2}{|c|}{$\begin{array}{l}\text { Both landlord and } \\
\text { tenant. }\end{array}$} & \multicolumn{2}{|c|}{ Landlord only. } & \multicolumn{2}{|c|}{ Tenant only. } \\
\hline & Receipts. & $\begin{array}{l}\text { Percent- } \\
\text { age of } \\
\text { total. }\end{array}$ & Receipts. & $\begin{array}{l}\text { Percent- } \\
\text { age of } \\
\text { total. }\end{array}$ & Receipts. & $\begin{array}{l}\text { Percent- } \\
\text { age of } \\
\text { total. }\end{array}$ & Receipts. & $\begin{array}{l}\text { Percent- } \\
\text { age of } \\
\text { total. }\end{array}$ \\
\hline 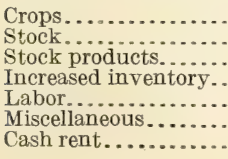 & $\begin{array}{r}\$ 858 \\
1,715 \\
143 \\
331 \\
26 \\
3\end{array}$ & $\begin{array}{r}27.9 \\
55.8 \\
4.6 \\
10.8 \\
.8 \\
.1\end{array}$ & $\begin{array}{r}\$ 1,333 \\
778 \\
111 \\
459 \\
20 \\
2\end{array}$ & $\begin{array}{r}49.3 \\
28.8 \\
4.1 \\
17.0 \\
.7 \\
.1\end{array}$ & $\begin{array}{r}\$ 677 \\
128 \\
8 \\
158 \\
\cdots \\
214\end{array}$ & $\begin{array}{r}57.1 \\
10.8 \\
.7 \\
13.3 \\
18.1 \\
18 . .\end{array}$ & $\begin{array}{r}\$ 657 \\
649 \\
103 \\
301 \\
20 \\
2\end{array}$ & $\begin{array}{r}37.9 \\
37.5 \\
5.9 \\
17.4 \\
1.2 \\
.1\end{array}$ \\
\hline Average or total. & 3,076 & 100.0 & 2,703 & 100.0 & 1,185 & 100.0 & 1,732 & 100.0 \\
\hline
\end{tabular}


$2 \frac{1}{4}$ to $2 \frac{1}{2}$ pounds of twine per acre are ordinarily used. Thrashing charges were approximately 2 cents a bushel for oats and 4 cents for wheat, plus the cost of coal used.

The average value of the farm buildings on the owner farms was $\$ 2,401$, and on the tenant farms, $\$ 1,652$. If we include the cost of new buildings and cash repairs, the annual charge is 5.2 per cent of the building investment on the owner farms and 4.4 per cent on those rented. These percentages are higher than they would be in a region that has been settled longer and where fewer new buildings were being erected.

The average amount invested in farm machinery and tools on the owner farms is $\$ 391$. The annual expense for new machinery and cash repairs is 16.9 per cent of the inventory value. This amounts to 50 cents per crop acre per year. On the rented farms the average amount invested is $\$ 368$, and the cash paid out for new machinery, harness, and repairs is 21.2 per cent of the inventory value. This makes a cost of 56 cents per crop acre. It is expected that the cost would be higher on the latter, as men just starting in farming as tenants would be likely to purchase more new machinery.

\section{RELATION OF PROFITS TO THE EFFICIENCY OF THE FARMER.}

Of the 273 farms operated by owners, one-third of them make a minus labor income. Analysis of their farm business should show the reasons why so many of these men failed to receive anything for their labor. Is it because of poor crops, inferior stock, improper organization of the farm, or merely plain indifference on the part of the farmer? It may justly be said that all these factors are contributing causes.

Leaving out of consideration the limitations set by the size of the farm and the capital invested, the characteristics of the inefficient farmer stand out prominently. Economically speaking, the greatest losses figured on the basis of a labor income are due to indifference or contentment on the part of the farmer. His farm area and capital are sufficient to earn a substantial income. He fails through neglect of work, low crop yields, inefficient stock, poor farm organization, and unused capital. His expenses are the same per acre as those of good farmers. His receipts are the weak point. His neighbors succeed, not by spending less, but by taking in more.

The size of the farm must also be considered in figuring losses, but large losses are not probable in a small business. The little farmer may lose all he has, but the greatest amount he can lose is small.

$$
13131^{\circ}-14-3
$$


The relation of profits to the efficiency of the farmer is shown in Table XI.

TABLE XI.-Relation of profits to the efficiency of the farmer on 27.3 farms operated by owners in Indiana, Illinois, and Iowa.

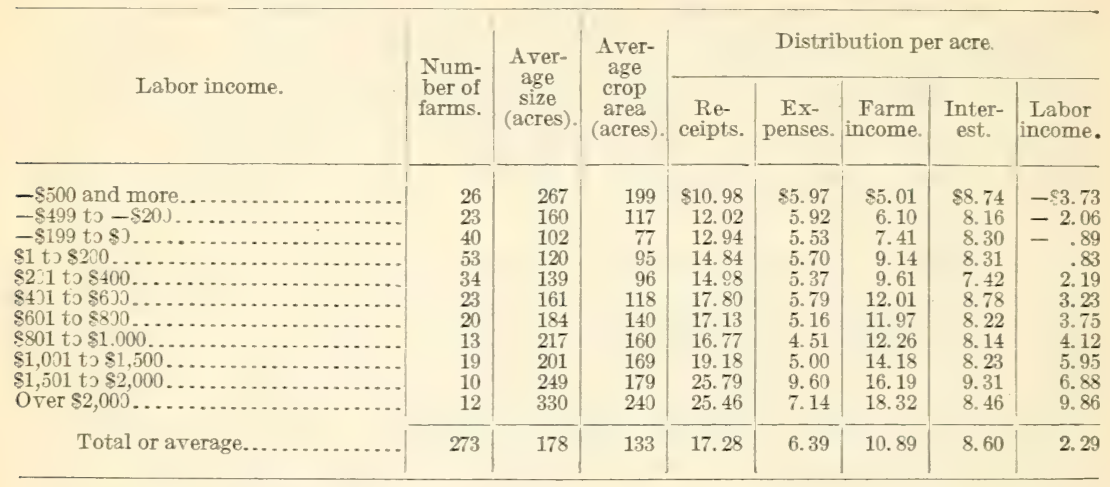

In Table XI the farms are classified according to labor income. The men making the poorest and those making the best profits hare large farms. Those just " breaking even " hare, on an arerage, small farms.

Many of these men are also poor farmers, but they can not be expected to do as well as those working a large area. The do not find the gross inefficiency among the tenants. for they must earn the rent which goes to the landlord, and if they receive nothing for their labor they can not live. They hare no interest on which to live, as does the farm owner with a large investment. The country wonld be benefited if the few inefficient farm owners on the large farms were persuaded to rent their farms to enterprising tenants. They would still hare as much or more than they are now getting. and the tenant would have a good living.

\section{FARM CAPITAL.}

It is difficult to realize the immense wealth embodied in the farms of the Torth Central States. The broad expanse of rich land, ranging in ralue from $\$ 100$ to $\$ 200$ an acre, constitutes an enormous resource. Owing to the extreme rariations in capital, the number of farms included in the survey are too few to permit a careful study of the influence of the size of inrestment on profits. Of the 273 farm owners only 9 had less than $\$ 5.000$ capital. while 50 per cent of them had more than $\$ 20,000$.

Generally speaking, the farmer's capital is in about the same proportion as the size of his farm. especially in a region of comparatively uniform land values. If the men with large capita 
are making better incomes, it means that the larger farms are paying better.

RELATION OF THE OWNER'S CAPITAL TO HIS INCOME.

In Table XII is shown the relation of capital to labor income on the 273 farms operated by owners.

TABLE XII.-Relation of the farm owner's capital to his income on 273 farms in Indiana, Illinois, and Iowa.

\begin{tabular}{|c|c|c|c|c|c|}
\hline Capital. & $\begin{array}{l}\text { Number } \\
\text { of farms. }\end{array}$ & $\begin{array}{l}\text { Average } \\
\text { labor in- } \\
\text { come. }\end{array}$ & Capital. & $\begin{array}{l}\text { Number } \\
\text { of farms. }\end{array}$ & $\begin{array}{l}\text { A verage } \\
\text { labor in- } \\
\text { come. }\end{array}$ \\
\hline \multirow{2}{*}{ 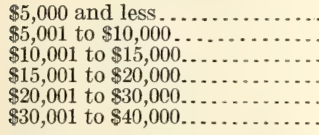 } & \multirow{2}{*}{$\begin{array}{r}9 \\
37 \\
44 \\
45 \\
55 \\
32\end{array}$} & \multirow{2}{*}{$\begin{array}{r}\$ 74 \\
45 \\
283 \\
265 \\
264 \\
483\end{array}$} & \multirow{2}{*}{$\begin{array}{r}\$ 40,001 \text { to } \$ 60,000 \ldots \\
\$ 60,001 \text { to } \$ 80,000 . . \\
\$ 80,001 \text { and over ... } \\
\\
\text { Average..... }\end{array}$} & $\begin{array}{l}29 \\
10 \\
12\end{array}$ & $\begin{array}{r}\$ 315 \\
1,114 \\
1,804\end{array}$ \\
\hline & & & & ......... & 408 \\
\hline
\end{tabular}

It will be noticed that of the entire number 9 men with less than $\$ 5,000$ capital received $\$ 74$ for their year's work. Only 2 farmers out of 46 with less than $\$ 10,000$ invested made over $\$ 400$. Out of the entire 273 only 12 men received over $\$ 2,000$ labor income. Each of these had more than $\$ 20,000$ invested. The chance of a farm owner making a labor income of $\$ 1,000$ with less than $\$ 15,000$ invested is less than 1 in 20.

The data in other tables are conclusive in showing more efficient use of man, horse, and machine labor on the large farms. The results also show no appreciable difference in the crop vields obtained on the different-sized farms. When the same system of farming is followed, larger returns must result on the larger farms. Men who have large capital invested and who operate the big farms have a right to expect greater returns for the risk and responsibility incurred. Of course, if the type of farming followed is an unprofitable one, then the large farms will necessarily show large losses. The area a farmer works limits the use of his labor. The amount of capital he has invested limits the income from that source.

\section{RELATION OF LABOR INCOME TO THE DISTRIBUTION OF OWNER'S CAPITAL.}

The farm owner has about six-sevenths of his total capital invested in land and buildings. The balance is largely in live stock, there being only a small percentage in machinery, tools, and supplies. Farmers making good incomes have their capital invested in very much the same manner as those receiving poor incomes. Table XIII shows the distribution of capital for the 273 farm owners, arranged according to the incomes they receive. 
TABLE XIII.-Relation of the labor income to the distribution of capital on 273 farms operated by their owners in Indiana, Illinois, and Iowa.

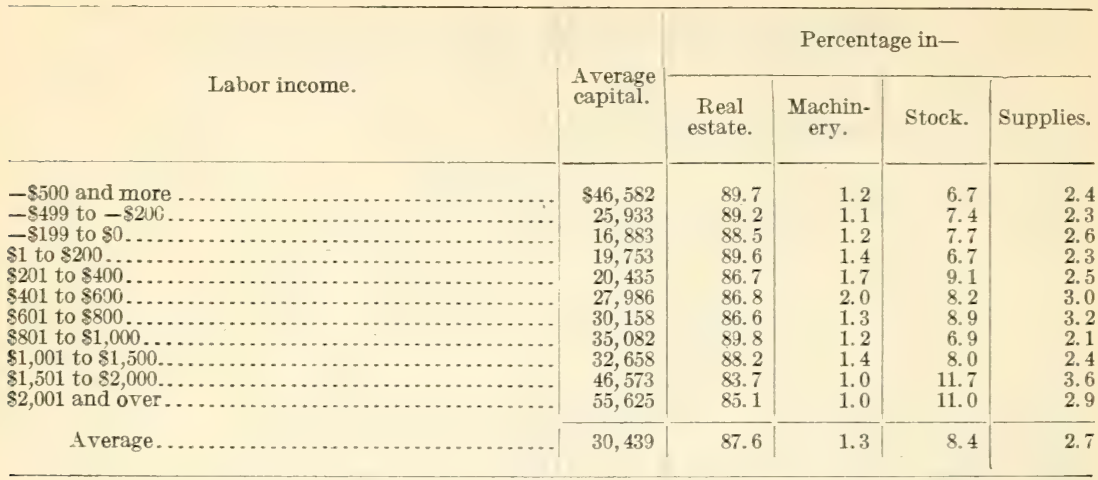

It will be noted that the men having the lowest incomes have nearly as much capital as those haring the highest. A large business is necessary to incur large losses; similarly, large incomes can not be expected from small investments. Small incomes usually attend small businesses. Where land values are high, the amount of money invested in working capital becomes proportionately small.

\section{DISTRIBUTION OF THE TENANT'S CAPITAL.}

The tenants in the States reported upon have less than 10 per cent as much capital as the owners. This is shown in Table XIV.

TABLE XIV.-Average aistribution of the tenant's capital on 247 farms in Indiana, Illinois, and Iowa.

\begin{tabular}{|c|c|c|c|c|}
\hline Distribution of eapital. & Indiana. & Mlinois. & Iowa. & $\begin{array}{l}\text { General } \\
\text { average. }\end{array}$ \\
\hline Average total. . & $\$ 1,644$ & $\$ 2,740$ & $\$ 2,459$ & $\$ 2,281$ \\
\hline 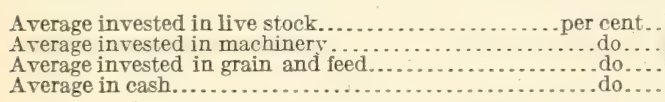 & $\begin{array}{r}62.0 \\
14.5 \\
15.1 \\
8.4\end{array}$ & $\begin{array}{r}63.8 \\
13.9 \\
14.3 \\
8.0\end{array}$ & $\begin{array}{r}66.2 \\
13.7 \\
14.1 \\
6.0\end{array}$ & $\begin{array}{r}64.0 \\
14.0 \\
14.5 \\
7.5\end{array}$ \\
\hline
\end{tabular}

Two-thirds of the investment of the tenants is in live stock, a large part of which is work horses. In a region where the system of rental is for the landlord to furnish half of the working capital the amount needed by the tenant is less. Few landlords furnish any of the working capital on the farms studied in this survey.

\section{RELATION OF THE TENANT'S CAPITAL TO HIS INCOME.}

A farm owner having a large investment, nearly 90 per cent of which is in real estate, can let it lie idle or nearly so for the entire year. It is partly due to this indifference on the part of some farmers that all men with large capital fail to show good returns. 
These men being free of debt are content to make only a moderate living, even though their farms under ordinary management would return double the income they now produce.

The situation of a farm tenant is entirely different. He has his capital in live stock, work horses, and machinery. These are an expense to him unless used. They are the means whereby he can utilize capital in the form of land. Generally, unless a tenant has use for his teams and machinery he will dispose of them, as there is always a market for such equipment. The tenant has a small capital, and 5 per cent interest on it is not sufficient to give him a living; hence he must receive wages for labor. The farm owner with large capital may receive no labor income and only 2 per cent on his investment, yet have a comfortable living.

In Table XV the farms are divided according to the amount of the tenant's capital, to show its relation to his labor income.

TABLE XV.-Relation of the tenant's capital to his income on 247 farms in Indiana, Illinois, and Iowa.

\begin{tabular}{|c|c|c|c|c|c|c|c|}
\hline \multirow{2}{*}{ Tenant's capital. } & \multirow{2}{*}{$\begin{array}{l}\text { Number } \\
\text { of farms. }\end{array}$} & \multicolumn{2}{|c|}{ Tenant's average. } & \multirow{2}{*}{ Tenant's capital. } & \multirow{2}{*}{$\begin{array}{l}\text { Number } \\
\text { of farms. }\end{array}$} & \multicolumn{2}{|c|}{ Tenant's average. } \\
\hline & & Capital. & $\begin{array}{l}\text { Labor } \\
\text { income. }\end{array}$ & & & Capital. & $\begin{array}{c}\text { Labor } \\
\text { income. }\end{array}$ \\
\hline $\begin{array}{l}\$ 500 \text { and less } \ldots \ldots . \\
\$ 501 \text { to } \$ 1,000 \ldots \ldots . \\
\$ 1,001 \text { to } \$ 1,500 \ldots . \\
\$ 1,501 \text { to } \$ 2,000 \ldots .\end{array}$ & $\begin{array}{r}5 \\
21 \\
44 \\
48\end{array}$ & $\begin{array}{r}\$ 324 \\
799 \\
1,271 \\
1,758\end{array}$ & $\begin{array}{r}\$ 328 \\
338 \\
502 \\
655\end{array}$ & $\begin{array}{l}\$ 2,001 \text { to } \$ 3,000 \ldots . \\
\$ 3,001 \text { to } \$ 4,000 \ldots . \\
\$ 4,001 \text { to } \$ 6,000 \ldots . \\
\$ 6,001 \text { and over.... }\end{array}$ & $\begin{array}{r}66 \\
41 \\
14 \\
8\end{array}$ & $\begin{array}{r}\$ 2,439 \\
3,415 \\
4,808 \\
8,657\end{array}$ & $\begin{array}{l}\$ 915 \\
1,095 \\
1,796 \\
2,879\end{array}$ \\
\hline
\end{tabular}

\section{RELATION OF BOTH THE TENANT'S AND LANDLORD'S CAPITAL TO THEIR INCOME.}

Table XVI gives the relation of tenant's and landlord's capital to the incomes they receive for the regions surveyed in each of the three States.

TABLE XVI.-Relation of the tenant's and the landlord's capital to the income received on 247 farms in Indiana, Illinois, and Iowa.

Operated by Tenants in Indana (83 Farms).

\begin{tabular}{|c|c|c|c|c|c|}
\hline Tenant's capital. & $\begin{array}{l}\text { Number } \\
\text { of farms. }\end{array}$ & $\begin{array}{l}\text { Tenant's } \\
\text { average } \\
\text { capital. }\end{array}$ & $\begin{array}{l}\text { Tenant's } \\
\text { labor } \\
\text { income. }\end{array}$ & $\begin{array}{l}\text { Landlord's } \\
\text { average } \\
\text { capital. }\end{array}$ & $\begin{array}{l}\text { Landlord's } \\
\text { income on } \\
\text { investment. }\end{array}$ \\
\hline 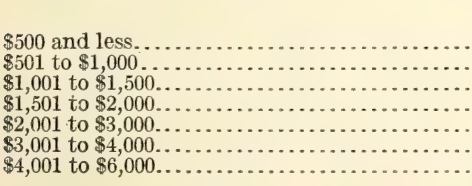 & $\begin{array}{r}5 \\
13 \\
18 \\
19 \\
18 \\
8 \\
2\end{array}$ & $\begin{array}{r}\$ 324 \\
750 \\
1,263 \\
1,726 \\
2,381 \\
3,324 \\
4,770\end{array}$ & $\begin{array}{r}\$ 328 \\
312 \\
506 \\
765 \\
1,051 \\
1,217 \\
2,322\end{array}$ & $\begin{array}{r}\$ 9,492 \\
9,940 \\
12,829 \\
17,679 \\
22,130 \\
34,904 \\
54,088\end{array}$ & $\begin{array}{r}\text { Per cent. } \\
4.0 \\
2.9 \\
3.1 \\
3.0 \\
3.6 \\
4.0 \\
4.4\end{array}$ \\
\hline Total or average for Indiana.... & 83 & 1,758 & 755 & 18,425 & 3.5 \\
\hline
\end{tabular}


TABLE X'I.-Relation of the tenant's and the landlord's capital, etc.-Continued. Operated by Tenants in IliLnois (71 Farms).

\begin{tabular}{|c|c|c|c|c|c|}
\hline Tenant's capital. & $\begin{array}{l}\text { Number } \\
\text { of farms. }\end{array}$ & $\begin{array}{l}\text { Tenant's } \\
\text { average } \\
\text { capital. }\end{array}$ & $\begin{array}{l}\text { Tenant's } \\
\text { labor } \\
\text { income. }\end{array}$ & $\begin{array}{l}\text { Landlord's } \\
\text { average } \\
\text { capital. }\end{array}$ & $\begin{array}{l}\text { Landlord's } \\
\text { income on } \\
\text { investment. }\end{array}$ \\
\hline 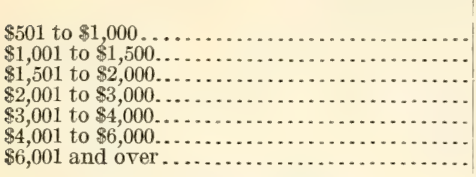 & $\begin{array}{r}4 \\
10 \\
15 \\
18 \\
15 \\
4 \\
5\end{array}$ & $\begin{array}{r}\$ 871 \\
1,262 \\
1,733 \\
2,482 \\
3,493 \\
4,828 \\
9,011\end{array}$ & $\begin{array}{r}\$ 429 \\
614 \\
709 \\
1,054 \\
1,085 \\
1,732 \\
4,117\end{array}$ & $\begin{array}{r}\$ 10,031 \\
23,737 \\
29,703 \\
36,948 \\
42,898 \\
50,950 \\
70,750\end{array}$ & $\begin{array}{c}\text { Per cent. } \\
2.7 \\
3.5 \\
4.1 \\
4.05 \\
3.3 \\
3.6 \\
3.1\end{array}$ \\
\hline Total or average for Illinois........... & 71 & 2,867 & 1,139 & 36,479 & 3.6 \\
\hline
\end{tabular}

Operated by Tenants in IOWA (93 Farms).

\begin{tabular}{|c|c|c|c|c|c|}
\hline 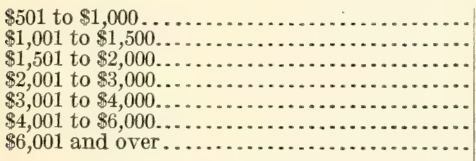 & $\begin{array}{r}4 \\
16 \\
14 \\
30 \\
18 \\
8 \\
3\end{array}$ & $\begin{array}{r}\$ 776 \\
1,288 \\
1,816 \\
2,455 \\
3,428 \\
4,825 \\
8,303\end{array}$ & $\begin{array}{r}\$ 272 \\
387 \\
490 \\
639 \\
983 \\
1,334 \\
1,641\end{array}$ & $\begin{array}{l}\$ 8,568 \\
13,808 \\
16,971 \\
19,374 \\
25,027 \\
31,490 \\
50,412\end{array}$ & $\begin{array}{l}3.2 \\
3.0 \\
2.8 \\
3.0 \\
3.2 \\
3.2 \\
4.7\end{array}$ \\
\hline Total or average for Iowa.............. & 93 & 2,667 & 716 & 20,728 & 3.2 \\
\hline
\end{tabular}

Almost without exception the tenant's income is in direct proportion to the sum he has invested (fig. 4). This is a very encouraging fact in that it shows that a tenant is able to acquire sufficient capital to become an owner. Many farmers begin as hired men. After a few years they save enough money or acquire credit so that they can rent a farm. This gires them a start, even though it may be a small place at the outset. By renting, the income is increased over the amount that could be earned as a hired man, and in a few years the tenant is able to establish sufficient credit or save enough to enable him to rent a larger place.

\section{ONE REASON WHY TENANTS CHANGE FARMS.}

Men who start in as tenants usually have very little capital and are limited in the size of the farm business they can select. After a few years of work they have enough teams and equipment to rent a larger farm, which will pay them increased returns for their year's labor. The changing of tenants from one farm to another is thus frequently a transitory step by young men seeking to become farm owners. If these same men were compelled to start on a small place and stay there for a long period of years they could never hope to eventually become owners, but by selecting farms which will use their entire working capital to its maximum they are able to advance rapidly. The income that a tenant receives with a capital of $\$ 1,000$ to $\$ 6,000$ is decidedly greater than that which he would have if he purchased a farm with that amount. No farm owner with less than a $\$ 20,000$ investment received a labor income of over $\$ 2,000$, while 1 tenant out of every 22 received this income with less than $\$ 6,000$ capital. 
Of course, in order to make a substantial income, the tenant must have the use of a large amount of capital, which is furnished by the landlord. The system of renting as practiced in the corn belt today is particularly well suited to the tenant's advancement. Not only is he free to move from a small to a larger farm as soon as he acquires sufficient working capital, but the returns that he receives from his investment are exceedingly large. Tenants as a rule avoid small farms. They are not large enough to pay the interest on the capital and leave anything for labor. The amount of capital that a tenant needs to operate a certain-sized farm depends quite largely on the type of farming that he wishes to follow and also on the system of rental.

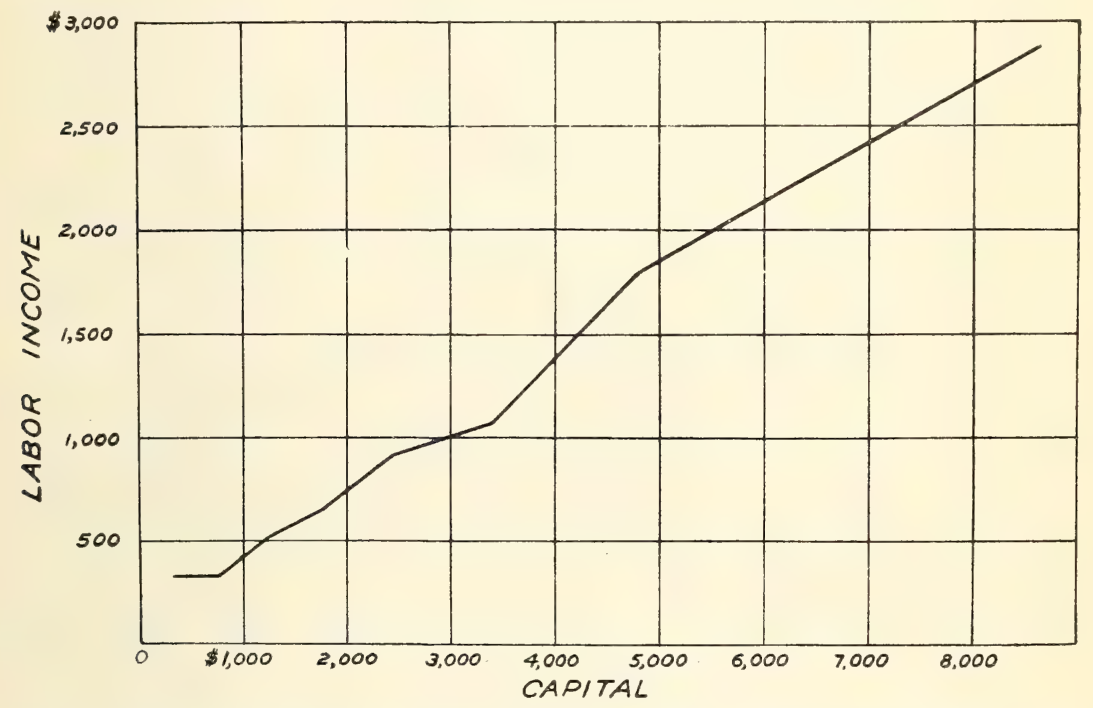

FIG. 4.-Chart showing the relation of the tenant's labor income to the capital he has invested.

In the case of live-stock farmers, some landlords furnish half of the live stock. Few, if any, furnish any of the work stock or equipment.

In the case of a cash rental the tenant has to furnish everything, and if he wishes to follow the live-stock type of farming he needs to have a good-sized investment on the large farms.

The system of farming practiced in the corn belt is one which enables a tenant to work a large area of land with small capital. The machinery that is used is simple and inexpensive. The work horses are, perhaps, the largest investment.

\section{RELATION OF THE SIZE OF THE LANDLORD'S INVESTMENT TO HIS INCOME.}

The size of the landlord's investment apparently makes little difference in the percentage of income, as shown in the preceding tables. 
It is highly important that the tenant have sufficient working capital, which necessitates a medium-sized farm to permit him to use it efficiently. The tenant, no matter what area of farm he is operating, must first pay rent, even though he has nothing left for his labor. The only disadvantage the landlord has in owning a small farm is that there may be difficulty in renting it.

\section{RELATION OF THE SIZE OF THE FARM TO THE PROFITS.}

According to the last census the farms in the North Central States are growing fewer in number and larger in area. The use of improved machinery and the expansive type of farming followed have been important factors in rendering the small farm a less efficient unit.

The term "small farm" as used throughout this bulletin is understood to be synonymous with small business. Under an intensive system of agriculture a very large business may be conducted on a small area, but in the corn belt, especially in the district covered by this survey, none but an expansive type of farming is found.

A very good indication of the relative returns that can be expected from 40 -acre, 80 -acre, and 160 -acre farms is given in Table XVII.

TABIE XVII.-Comparison of labor incomes on 40-acre, 80-acre, and 160-acre farms in Indiana, Illinois, and Iowa.

\begin{tabular}{|c|c|c|c|c|c|c|}
\hline \multirow{2}{*}{ Item. } & \multicolumn{3}{|c|}{$\begin{array}{l}\text { Operated by owners } \\
\text { ( } 71 \text { farms). }\end{array}$} & \multicolumn{3}{|c|}{$\begin{array}{l}\text { Operated by tenants } \\
\text { (66 farms). }\end{array}$} \\
\hline & $\begin{array}{l}\text { 40-acre } \\
\text { farms. }\end{array}$ & $\begin{array}{l}80 \text {-acre } \\
\text { farms. }\end{array}$ & $\begin{array}{l}\text { 160-acre } \\
\text { farms. }\end{array}$ & $\begin{array}{l}\text { 40-acre } \\
\text { farms. }\end{array}$ & $\begin{array}{l}80 \text {-acre } \\
\text { farms. }\end{array}$ & $\begin{array}{l}\text { 160-acre } \\
\text { farms. }\end{array}$ \\
\hline Number of farms....................... & 20 & 26 & 25 & 1 & 28 & 37 \\
\hline $\begin{array}{l}\text { Number of farms witn incomes of } \$ 1,000 \text { or } \\
\text { more. }\end{array}$ & 0 & & & & & \\
\hline 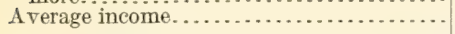 & $\$ 70$ & $\$ 266$ & $\$ 364$ & $\$ 264$ & $\$ 440$ & $\$ 904$ \\
\hline
\end{tabular}

Of all the farms operated by owners there were 20 of just 40 acres in area, the average labor income of which was $\$ 70$. None made a labor income of $\$ 1,000$. There were 26 men on 80 -acre farms and only one of them made a labor income of $\$ 1,000$. Of the 25 men on 160 -acre farms one in five made $\$ 1,000$ or more.

Only one tenant rented a 40 -acre farm, and he had less than $\$ 300$ for his year's living. Most tenants know better than to rent such a small farm, fully realizing the improbability of a good income. The average income of the 37 tenants on 160 -acre farms was $\$ 904$. More than one in every three made a labor income of $\$ 1,000$. If the man on the 40-acre farm in Illinois or in any of the North Central States expects to have as good a living as his neighbor on 160 acres he must produce four times as much per acre with no increase in expenses.

In Table XVIII the farms are arranged according to their size to show the relation existing between the area of the farm and the income received. 
TABIE XVIII.-Relation of the size of farm to the income on 273 farms operated by owners in Indiana, Illinois, and Iowa.

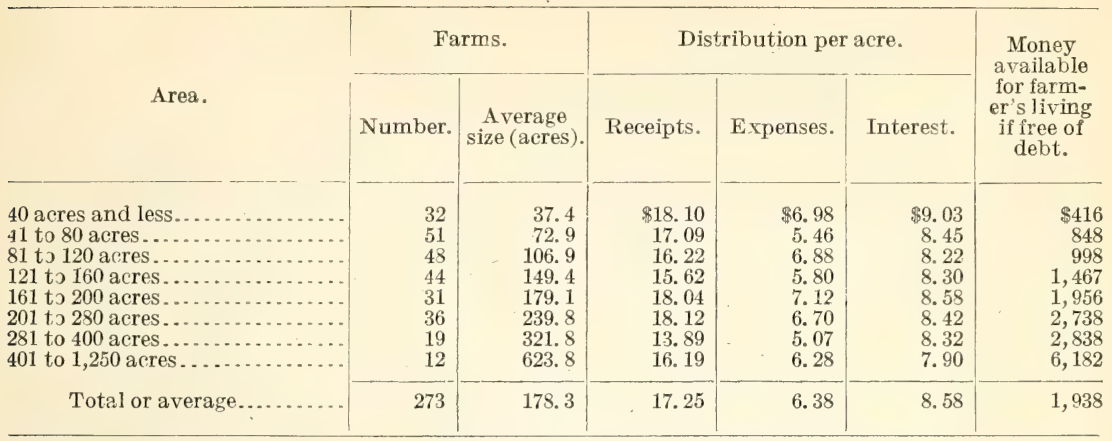

The receipts per acre are practically the same on the small and large farms. The expenses are also the same. If greater intensity were practiced on the small areas, larger receipts to the acre would be the result.

If the farmer is free of debt he has available for his living the amount shown in the right-hand column of Table XVIII. This amount represents the combined income from capital and labor.

The results of the 1910 census show that nearly one-half of the farm owners in the counties from which the survey records were taken have mortgages on their farms. The amount of the mortgage is approximately one-fourth of the total farm investment. It is not hard to understand why the small farmer is less efficient. Just as long as he continues to grow such crops as corn, oats, wheat, and hay his income will be meager. The only possible remedy is more land. He may either rent or buy, according to his available funds.

On the other hand, if the man on the small place should change his type of farming so that he could grow crops returning a high income per acre, he would then have possibilities of a much greater income. A farm is a place to work, and unless it is so organized to permit the full use of labor small wages must result.

There are a few highly specialized farms which return a high rate of income per hour of labor. However, these farms are not found where corn and oats are the leading crops. The introduction of good live stock in a measure helps toward utilizing more labor, but even this step will seldom suffice to give the small farmer an income comparable with that of the man on 160 acres or more. Thus, the decrease in the number of farms in the North Central States is no cause for alarm. It is rather a sign that land is being utilized more efficiently and that the same products are being produced at less cost. 


\section{RELATION OF THE SIZE OF THE FARM TO THE EFFICIENCY OF OPERATION.}

The size of a farm is the controlling factor in the efficient use of farm labor and machinery. The old hand-labor methods practiced by our forefathers, which are still common in Europe, were suited to a small area. Under those conditions a man needed only as much land as he could properly cultirate alone. A family was able to raise only a small amount abore that needed for their own living. If these methods still prevailed in this country, the present number of farmers would be entirely inadequate to support our urban population.

The adoption of modern machinery has enormously increased the efficiency of the farm worker. Fewer men are now needed in the farming districts, and those not needed are able to derote themselves to useful work in the cities and towns. As a result of this condition more of the benefits of cirilization are arailable to the farmer. Although the farmers are ferer in number, the production per man is increasing.

If hand labor could compete with machine work, farm wages would be much less and the product per man proportionately smaller. Our agricultural civilization would then gravitate toward the peasant conditions existing in some parts of Europe, where the agriculture is dereloped on the basis of the maximum product per acre of land instead of the maximum product per man.

\section{RELATION OF THE SIZE OF THE FARM TO THE USE OF MAN LABOR.}

In Table XIX the farms are classified according to their total area. The cost of labor includes all paid labor, board of workmen, family labor, and the estimated value of the operator's labor. The ralue of the family, or unpaid, labor is explained on page 9 . The tenants estimated their mork as worth $\$ 36 \pi$, and the owners estimated theirs at $\$ 363$, or an average of $\$ 365$ for all the farmers.

The term "crop area," as used in the following tables, includes all tillable area except permanent pasture.

TABLE XIX.-Relation of the size of the farm to the cost of man labor per acre on 700 farms in Indiana, Iltinois, and Iova.

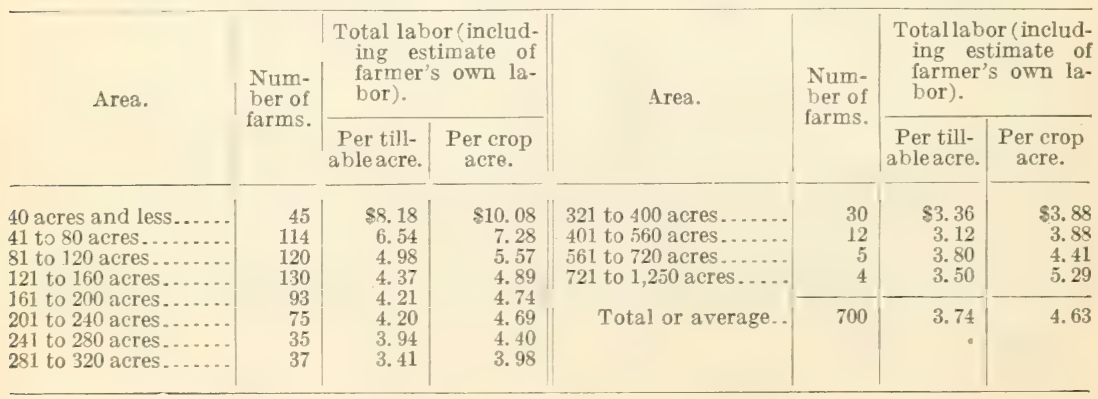


On farms of 40 acres and less the cost of labor is over $\$ 10$ per crop acre. On all farms above 120 acres the cost is less than $\$ 6$ per crop acre. This increased efficiency of man labor on the larger farms constitutes an important factor in the cost of crop production.

\section{RELATION OF THE SIZE OF THE FARM TO THE EFFICIENCY OF WORK HORSES.}

With the prevailing type of agriculture as found in the corn belt, both man and horse need more land to work. Farms with less than 100 acres in crops are not utilizing horse labor nearly as efficiently as the larger places. On farms of 40 acres one horse works less than 10 crop acres, while on farms of 240 acres or more one horse works two and one-half times as much land. One of the difficulties with a farm of less than 40 acres in the corn belt is that it requires the same number of horses for certain farm operations as the larger place. The area in crops is so limited that only a small part of the avajlable horse labor can be utilized.

The labor demand of such crops as corn and oats is not evenly distributed through the growing season; hence, horses remain idle for a large part of the time. If men on the small farms were following a different type of agriculture, it would be possible to utilize the horses more efficiently by growing crops which require a large amount of horse labor per acre. By means of diversification of crops so as to better distribute their labor these men may succeed in competing with those on the large places.

The relation of the size of the farm to the number of crop acres on which a horse can be utilized is shown in Table XX.

TABLE XX.-Relation of the size of the farm to the number of crop acres on which a horse can be utilized on 700 farms in Indiana, Illinois, and Iovo.

\begin{tabular}{|c|c|c|c|c|c|}
\hline \multirow[b]{2}{*}{ Area. } & \multicolumn{4}{|c|}{ Farms. } & \multirow[b]{2}{*}{$\begin{array}{c}\text { Crop area } \\
\text { per horse } \\
\text { (acres). }\end{array}$} \\
\hline & Number. & $\begin{array}{c}\text { Average } \\
\text { size (acres). }\end{array}$ & $\begin{array}{c}\text { Average } \\
\text { crop area } \\
\text { (acres). }\end{array}$ & $\begin{array}{c}\text { Average } \\
\text { number of } \\
\text { work } \\
\text { horses. }\end{array}$ & \\
\hline 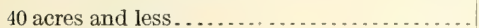 & 45 & 36.6 & 26.4 & 2.8 & 9.4 \\
\hline 41 to 80 acres. & .114 & 71.4 & 56.7 & 3.6 & 15. 7 \\
\hline 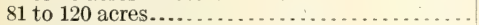 & 120 & 107.2 & 86.0 & 4.5 & 19. 1 \\
\hline 121 to 160 acres. & 130 & 149.3 & 122.4 & 5.8 & 21.1 \\
\hline 161 to 200 acres. & 93 & 183.6 & 143.4 & 6.6 & 21.7 \\
\hline 201 to 240 acres. & 75 & 227.4 & 184.9 & 7.8 & 23.7 \\
\hline 241 to 280 acres. & 35 & 262.5 & 211. 2 & 8.4 & 25.1 \\
\hline 281 to 320 acres. . . . . . . . . . . . & $37^{2}$ & 305.6 & 233.8 & 9.5 & 24.6 \\
\hline 321 to 400 acres..... & 30 & 364.1 & 298.0 & 10.8 & 27.6 \\
\hline 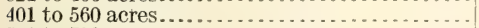 & 12 & 474.8 & 368.6 & 13.1 & 28.1 \\
\hline 561 to 720 acres. & 5 & 652.6 & 555.4 & 19.4 & 28.6 \\
\hline 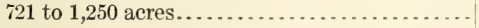 & 4 & 991.2 & 612.0 & 19.0 & 32.2 \\
\hline
\end{tabular}

To judge from the data given in Table XX, there is no marked increase in the efficiency of horse labor on the very large farms over the medium-sized ones. 


\section{RELATION OF THE SIZE OF THE FARM TO THE EFFICIENCY OF MACHINERY.}

In the regions studied, small farms do not permit as efficient use of machinery as those of medium size. The same laws which govern the use of farm labor apply to machinery. Land enough to allow the maximum use of machinery is the keynote to the whole situation. A certain equipment is needed and this is much the same on a 60 acre as on a 160-acre farm. A farm may be of such size as to require two sets of certain implements, yet not large enough to permit the maximum use of each.

Figure $\check{5}$ illustrates the use of modern machinery and large teams for farm work. These are typical of the expansive type of farming found on the broad, level areas in the North Central States.

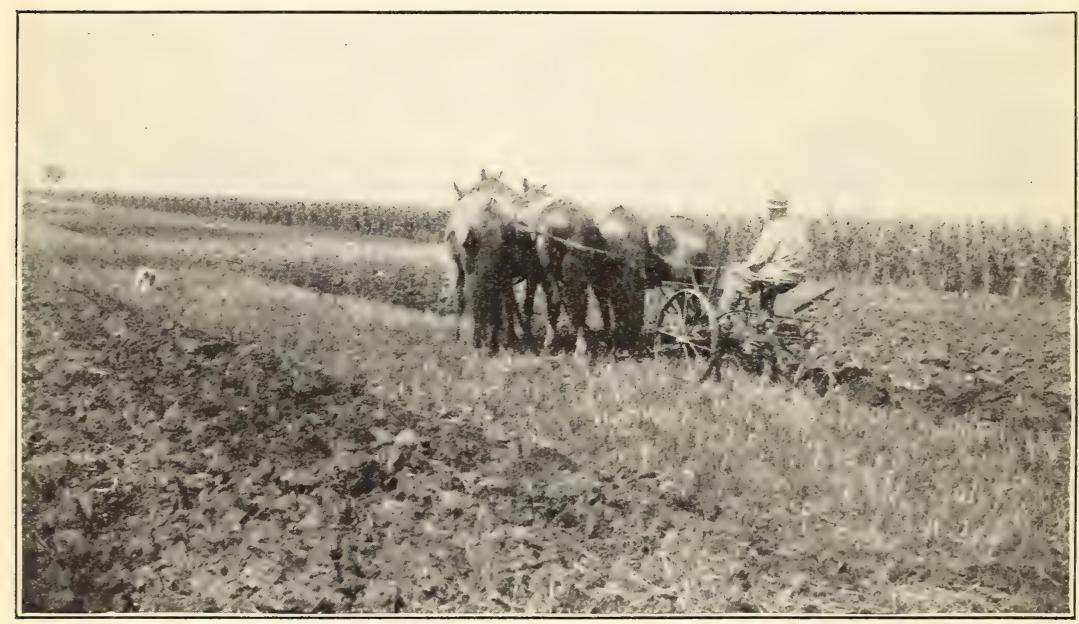

Fig. 5.-A sulky gang plow drawn by four horses. Modern machines with large teams, such as this, are used throughout these regions and utilize labor efficiently.

In Table XXI is given the machinery investment per crop acre on the different-sized farms.

TABLE XXI.-Relation of the size of the farm to the efficiency of machinery on ro0 farms in Indiana, Illinois, and Iowa.

\begin{tabular}{|c|c|c|c|c|c|}
\hline \multirow[b]{2}{*}{ Size of farm. } & \multicolumn{3}{|c|}{ Farms. } & \multicolumn{2}{|c|}{ Value of machinery. } \\
\hline & Number. & $\begin{array}{c}\text { Average } \\
\text { size (acres). }\end{array}$ & $\begin{array}{c}\text { Average } \\
\text { erop area } \\
\text { (acres). }\end{array}$ & $\begin{array}{l}\text { Total per } \\
\text { farm. }\end{array}$ & $\begin{array}{l}\text { Per crop } \\
\text { acre. }\end{array}$ \\
\hline 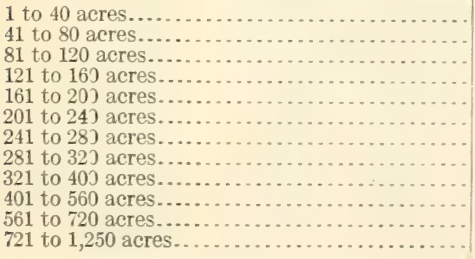 & $\begin{array}{r}45 \\
114 \\
120 \\
130 \\
93 \\
75 \\
35 \\
37 \\
30 \\
12 \\
5 \\
4\end{array}$ & $\begin{array}{r}\text { 36. } \\
71.4 \\
107.2 \\
149.3 \\
183.6 \\
227.4 \\
262.6 \\
305.6 \\
364.1 \\
474.8 \\
652.6 \\
991.25\end{array}$ & $\begin{array}{r}26.4 \\
56.7 \\
86.0 \\
122.4 \\
143.4 \\
181.9 \\
211.2 \\
233.8 \\
298.0 \\
368.6 \\
555.4 \\
612.0\end{array}$ & $\begin{array}{r}\$ 133 \\
241 \\
279 \\
345 \\
413 \\
452 \\
718 \\
561 \\
747 \\
690 \\
790 \\
1,313\end{array}$ & $\begin{array}{l}\$ 5.04 \\
4.25 \\
3.24 \\
2.82 \\
2.88 \\
2.44 \\
3.40 \\
2.40 \\
2.51 \\
1.87 \\
1.42 \\
2.15\end{array}$ \\
\hline
\end{tabular}


The results are the same for each district studied. The machinery cost on the small farm of 40 acres or less is double that on those over 200. As the area increases up to 100 acres there is a marked decrease in the machinery cost, but above this area the gain in efficiency is small or entirely lacking.

\section{RELATION OF THE SIZE OF THE FARM TO THE CROP YIELDS.}

Climatic conditions have such marked influence on crop yields that records for one year are of little value as a measure of the yields in a given region. However, such records do permit a comparison of yields on farms of different sizes when conducted under the same system of management.

It is generally believed that the small farm is more efficient owing to better crops. This appears to be a mistaken theory. The figures given in Table XXII show the average yields of corn, oats, and wheat on the large and small farms.

TABLE XXII.-Relation of the size of the farm to the yield of various crops.

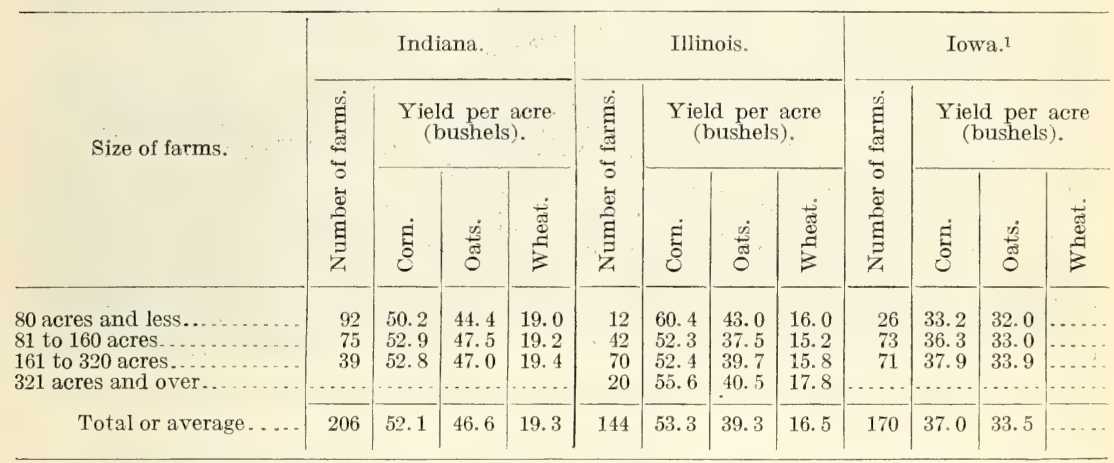

1 The yield of corn in Iowa in 1910 was much below normal, owing to drought in early summer.

In Indiana higher yields of both corn and oats were obtained on the larger farms. The difference is slight, yet 2.6 bushels of corn is worth considering.

In Illinois the highest yields of corn were secured on the smaller farms. On the other hand; the yields on larger farms, those exceeding 320 acres in size, excelled both groups, ranging in size from 81 to 320 acres. There were only 12 farms under 80 acres, too few from which to draw definite conclusions.

In Iowa the larger farms consistently had the better yields.

\section{RELATION OF THE TYPE OF FARMING TO THE INCOME.}

All the farmers in the regions studied are following the same general expansive system of agriculture, developed on the basis of maximum product per man. Within this system two important 
trpes are found. One is the crop farm, where 50 per cent or orer of the total farm receipts are derived from the sale of grain. The other trpe is the lire-stock farm, where the farmer markets his crops largely through hogs, horses, and beef cattle (fig. 6). The number of men following each type will rary greatly in different years, according to the relative price of cattle and hogs (figs. 7, 8, and 9).

One year's results are altogether too fer to form any substantial basis of comparison. The data are presented only to show the importance of the trpe of farming in relation to income. It is fully recognized that further studies in another rear under different conditions might easily show results just the reverse of these in regard to the best paying type of farming.

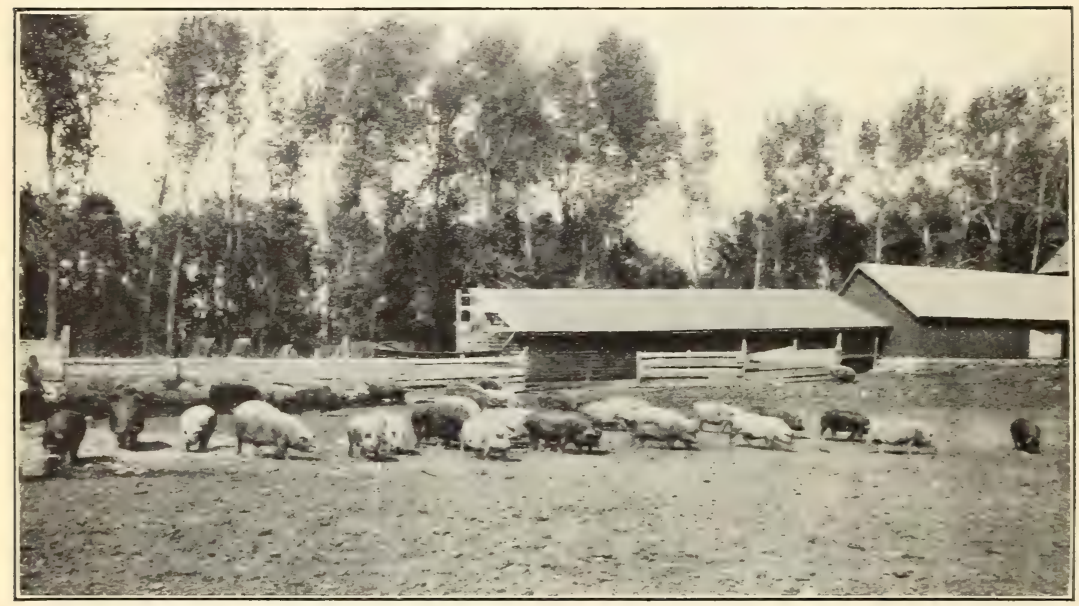

FIG, 6.-The type of hogs which are an important source of income on Iowa farms.

Of the 273 farm owners 194 were classed as lire-stock farmers and 79 as crop farmers. The arerage capital and income of each are given in Table XXIII.

TABLE XXIII.-Relation of the type of farming to the income on farms operater by ouners in Indiana. Illinois. and Iowa.

\begin{tabular}{|c|c|c|c|c|c|c|c|c|c|c|}
\hline \multirow{3}{*}{ State. } & \multicolumn{5}{|c|}{ Live-stock farms: } & \multicolumn{5}{|c|}{ Crop farms. } \\
\hline & \multicolumn{2}{|c|}{ Farms. } & \multirow{2}{*}{ 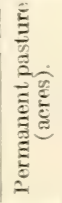 } & \multirow[b]{2}{*}{ 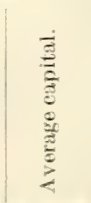 } & \multirow[b]{2}{*}{ 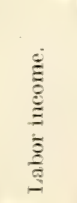 } & \multicolumn{2}{|c|}{ Farms. } & \multirow{2}{*}{ 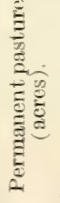 } & \multirow{2}{*}{ 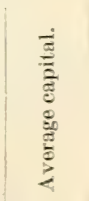 } & \multirow[b]{2}{*}{$\begin{array}{l}\stackrel{\Xi}{\Xi} \\
\stackrel{\Xi}{\Xi} \\
\vdots \\
\frac{\Xi}{\Xi}\end{array}$} \\
\hline & $\underset{⿱ 亠 幺}{\vdots}$ & 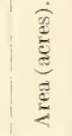 & & & & $\frac{\check{\Xi}}{\Xi}$ & 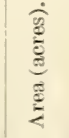 & & & \\
\hline 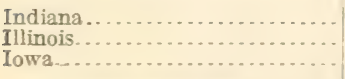 & $\begin{array}{l}95 \\
32 \\
67\end{array}$ & $\begin{array}{l}103.2 \\
281.2 \\
181.2\end{array}$ & $\begin{array}{r}5.6 \\
66.3 \\
40.1\end{array}$ & $\begin{array}{r}\$ 17,405 \\
58,487 \\
23,775\end{array}$ & $\begin{array}{r}\$ 348 \\
1,588 \\
329\end{array}$ & $\begin{array}{l}28 \\
41 \\
10\end{array}$ & $\begin{array}{l}113.0 \\
229.4 \\
140.9\end{array}$ & $\begin{array}{r}2.0 \\
24.4 \\
17.1\end{array}$ & $\begin{array}{r}817,981 \\
45,319 \\
19,296\end{array}$ & $\begin{array}{r}\$ 182 \\
-131 \\
34\end{array}$ \\
\hline Total or average... & 194 & 159.5 & 37.3 & 33.222 & 7.5 .5 & 79 & 161.1 & 14.5 & 27.532 & 28 \\
\hline
\end{tabular}


The live-stock men had a larger area and more capital and were receiving a much higher labor income. The average income of the
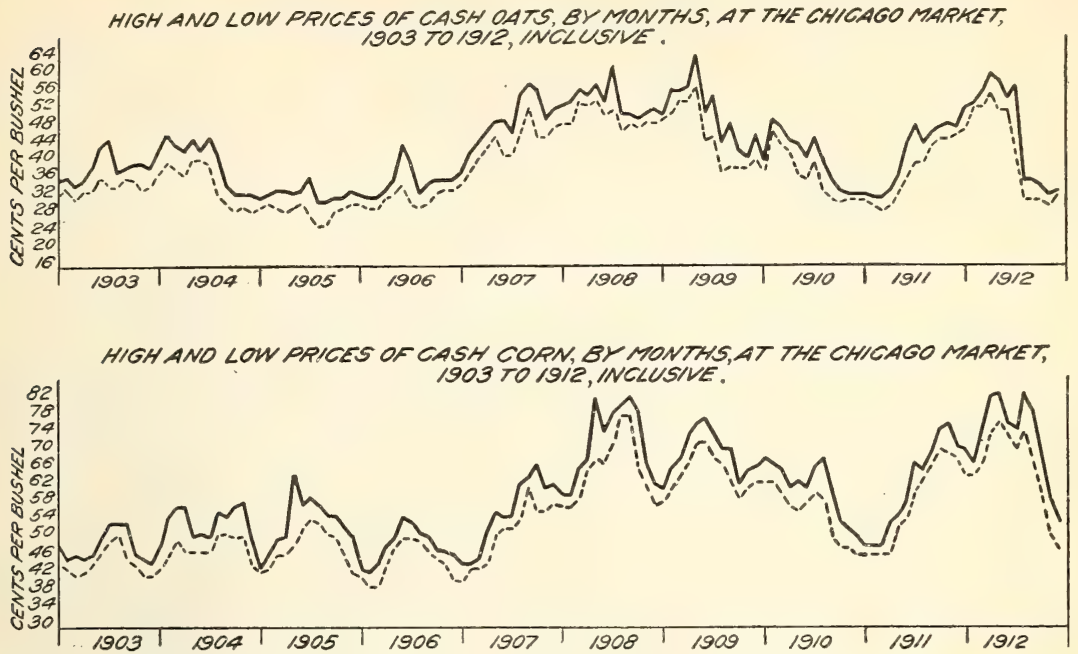

FIG. 7.-Chart showing the fluctuation in the prices of oats and corn in the Chicago market from 1903 to 1912, inclusive. (Data from the Live-Stock Daily Drovers Journal.)

crop farmer was $\$ 28$ per farm, and of the live-stock men $\$ 755$. This wide difference in favor of the live-stock farmer holds true in each of the States.

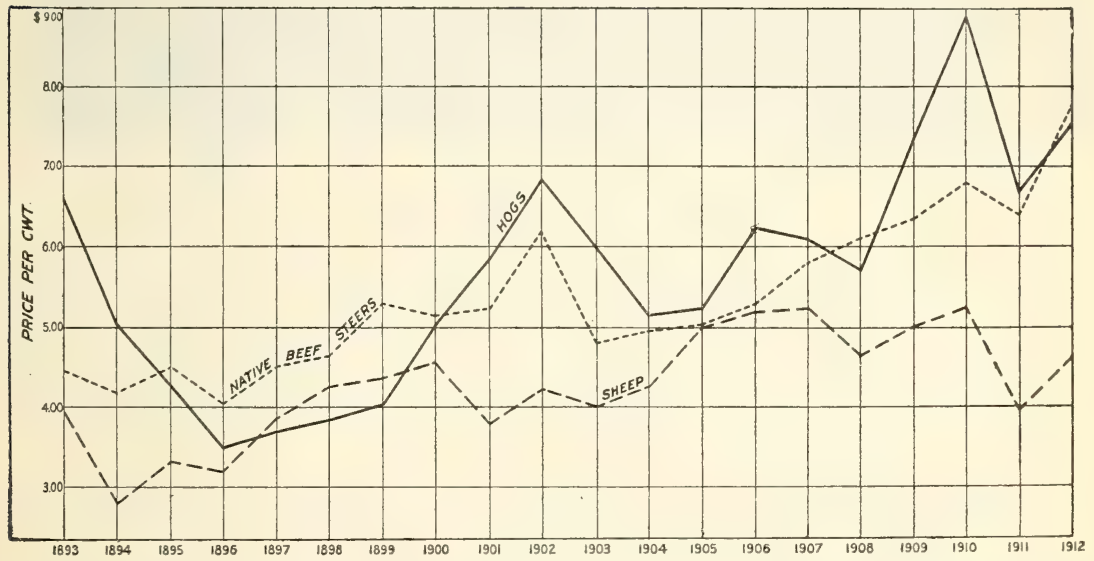

Fig. 8.-Chart showing the fluctuation in the prices of hogs, steers, and sheep in the Chicago market from 1593 to 1912 , inclusive. (Data from the Live-Stock Daily Drovers' Journal.)

In the case of the tenant farms, the results of which are given in Table XXIV, the conclusions are practically the same. The data 
given in this table are for the entire farm, including both landlord and tenant.

TABLE XXIT.-Relation of the type of farming to the income on farms operated by tenants in Indiana, Illinois, and Iowa.

\begin{tabular}{|c|c|c|c|c|c|c|c|c|c|c|}
\hline \multirow[b]{3}{*}{ State. } & \multicolumn{5}{|c|}{ Live-stock farms. } & \multicolumn{5}{|c|}{ Crop farms. } \\
\hline & \multicolumn{2}{|c|}{ Farms. } & \multirow{2}{*}{ 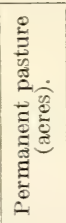 } & \multirow[b]{2}{*}{ 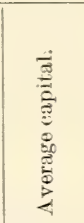 } & \multirow[b]{2}{*}{ 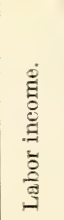 } & \multicolumn{2}{|c|}{ Farms. } & \multirow{2}{*}{ 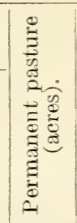 } & \multirow[b]{2}{*}{ 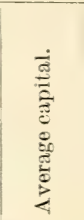 } & \multirow[b]{2}{*}{ 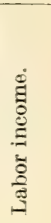 } \\
\hline & 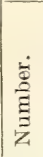 & 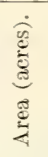 & & & & 离 & 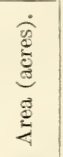 & & & \\
\hline $\begin{array}{l}\text { Indiana..... } \\
\text { nlinois...... } \\
\text { Iowa....... }\end{array}$ & $\begin{array}{l}46 \\
13 \\
58\end{array}$ & $\begin{array}{l}124 \\
198 \\
179\end{array}$ & $\begin{array}{r}4 \\
30 \\
37\end{array}$ & $\begin{array}{r}\$ 19,623 \\
42,087 \\
23,238\end{array}$ & $\begin{array}{r}\$ 589 \\
1,066 \\
496\end{array}$ & $\begin{array}{l}37 \\
58 \\
35\end{array}$ & $\begin{array}{l}134 \\
204 \\
199\end{array}$ & \begin{tabular}{r|r}
4 & \\
12 \\
30
\end{tabular} & $\begin{array}{r}\$ 20,879 \\
38,732 \\
23,654\end{array}$ & $\begin{array}{r}\$ 354 \\
545 \\
82\end{array}$ \\
\hline Total or average . & 117 & 167 & 24 & 28,316 & 717 & 130 & 179 & 15.3 & 27,755 & 327 \\
\hline
\end{tabular}

On these farms the crop men had a larger area and nearly the same capital, yet their income was less than half that of the lire-stock men. This wide margin of profit in favor of the live-stock farmer

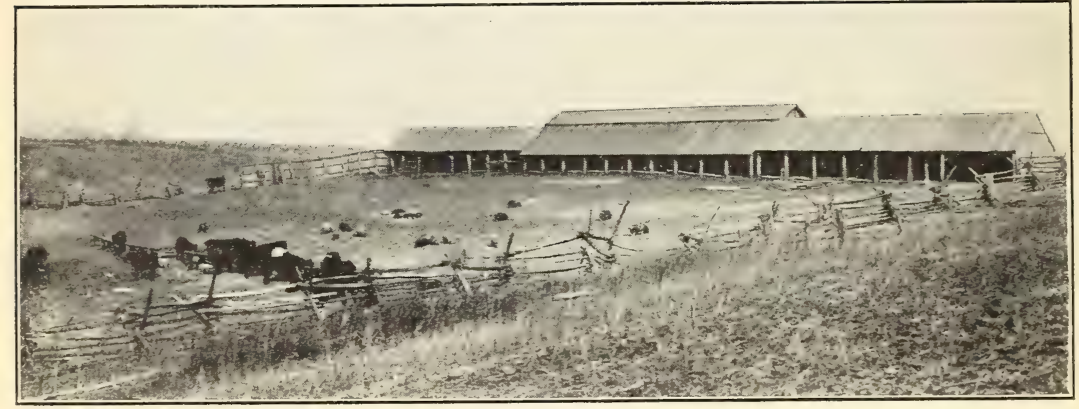

FIG. 9.-Beef cattle and hogs in a feed lot, showing a method of feeding which utilizes labor during the winter months.

is due primarily to two reasons, the most important of which is that the crop men sold their corn at about 41 cents per bushel. (See Table XXV.) The live-stock farmer fed his corn to hogs, which he sold at a price ranging from $7 \frac{1}{2}$ to 9 cents a pound. Many men also fed cattle, which likewise sold on a high market.

TABLE XXV.-Average price (in cents per bushel) received for crops sold on owner and tenant farms in Indiana, Illinois, and Iowa.

State.

\begin{tabular}{|c|c|c|c|c|c|}
\hline \multicolumn{2}{|c|}{ Corn. } & \multicolumn{2}{|c|}{ Oats. } & \multicolumn{2}{|c|}{ Wheat. } \\
\hline Owners. & Tenants. & Owners. & Tenants. & Owners. & Tenants. \\
\hline $\begin{array}{l}42.6 \\
42.9 \\
39.8\end{array}$ & $\begin{array}{l}41.1 \\
41.7 \\
38.7\end{array}$ & $\begin{array}{l}31.9 \\
32.3 \\
28.1\end{array}$ & $\begin{array}{l}32.4 \\
32.2 \\
28.3\end{array}$ & $\begin{array}{l}89.8 \\
95.6 \\
88.9\end{array}$ & $\begin{array}{l}92.3 \\
96.1 \\
88.2\end{array}$ \\
\hline
\end{tabular}


It is generally figured that a bushel of corn will produce 10 pounds of pork. If this is true, the crop farmer received only about half as much for corn as did the live-stock men. On the other hand, the stock farmer had losses due to disease, more expense, more labor, and a larger investment, but the difference in the relative prices of hogs and corn more than offset these factors.

Another reason the live-stock man did much better was because he utilized his labor. The crops grown in those regions do not fully utilize the farm labor throughout the year, but by having live stock the men had something to do during the winter months and were well paid for their work.

There have been periods in the history of the North Central States when the live-stock men received the smaller incomes, and they are likely to occur again. This condition will occur when there is a large overproduction of hogs and a short corn crop, thereby forcing the cash price of corn higher than could be obtained through feeding it. Experienced observers of the profitableness of farming in these States agree that the man who follows the practice of feeding his crops generally wins out in the long run. He will have his off years once in a while, but over a long period the chances are largely in his favor.

\section{COMPARISON OF YIELDS OF VARIOUS CROPS.}

It is commonly supposed that the live-stock farmers make greater profits, due to much better yields. The yields of corn, oats, and wheat on the two types of farms are given in Table XXVI.

TABLE XXVI.-Comparison of the crop yields on farms operated by owners and tenants in Indiana, Illinois, and Iowa.

\begin{tabular}{|c|c|c|c|c|c|c|c|c|}
\hline \multirow{4}{*}{ State. } & \multicolumn{8}{|c|}{ Operated by owners (273 farms). } \\
\hline & \multicolumn{4}{|c|}{ Live-stock farms. } & \multicolumn{4}{|c|}{ Crop farms. } \\
\hline & \multirow{2}{*}{$\begin{array}{l}\text { Num- } \\
\text { ber. }\end{array}$} & \multicolumn{3}{|c|}{ Yield per acre (bushels). } & \multirow{2}{*}{$\begin{array}{l}\text { Num- } \\
\text { ber. }\end{array}$} & \multicolumn{3}{|c|}{ Yield per acre (bushels). } \\
\hline & & Corn. & Oats. & Wheat. & & Corn. & Oats. & Wheat. \\
\hline $\begin{array}{l}\text { Indiana........ } \\
\text { Illinois........ } \\
\text { Iowa........ }\end{array}$ & $\begin{array}{l}95 \\
32 \\
67\end{array}$ & $\begin{array}{l}52 \\
60 \\
37\end{array}$ & $\begin{array}{l}47 \\
43 \\
35\end{array}$ & $\begin{array}{l}20 \\
17 \\
20\end{array}$ & $\begin{array}{l}28 \\
41 \\
10\end{array}$ & $\begin{array}{l}51 \\
51 \\
42\end{array}$ & $\begin{array}{l}49 \\
36 \\
35\end{array}$ & $\begin{array}{r}18 \\
18 \\
\ldots . .6\end{array}$ \\
\hline Total or average.................. & 194 & 50 & 42 & 19 & 79 & 48 & 40 & 18 \\
\hline
\end{tabular}

\begin{tabular}{|c|c|c|c|c|c|c|c|c|}
\hline \multirow{4}{*}{ State. } & \multicolumn{8}{|c|}{ Operated by tenants (247 farms). } \\
\hline & \multicolumn{4}{|c|}{ Live-stock farms. } & \multicolumn{4}{|c|}{ Crop farms. } \\
\hline & \multirow{2}{*}{$\begin{array}{l}\text { Num- } \\
\text { ber. }\end{array}$} & \multicolumn{3}{|c|}{ Yield per acre (bushels). } & \multirow{2}{*}{$\begin{array}{l}\text { Num- } \\
\text { ber. }\end{array}$} & \multicolumn{3}{|c|}{ Yield per acre (bushels). } \\
\hline & & Corn. & Oats. & Wheat. & & Corn. & Oats. & Wheat. \\
\hline 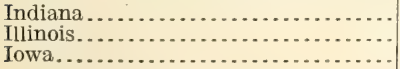 & $\begin{array}{r}46 \\
13 \\
58\end{array}$ & $\begin{array}{l}53 \\
59 \\
35\end{array}$ & $\begin{array}{l}45 \\
42 \\
31\end{array}$ & $\begin{array}{l}19 \\
15 \\
17\end{array}$ & $\begin{array}{l}37 \\
58 \\
35\end{array}$ & $\begin{array}{l}51 \\
51 \\
37\end{array}$ & $\begin{array}{l}46 \\
39 \\
34\end{array}$ & $\begin{array}{r}18 \\
15 \\
-\ldots\end{array}$ \\
\hline Total or average................ & 117 & 49 & 39.3 & 17 & 130 & 46 & 39.6 & 16.5 \\
\hline
\end{tabular}


There is a slight difference in rield in faror of the live-stock men. The results for the one rear are only an indication, further studies being needed to determine this point. Howerer, the difference in crop rields is not as great as many persons suppose. The larger profits of the lire-stock type of farming are due, primarily, to a better utilization of the farmer"s time and to the relative selling price of hogs and corn.

\section{SYSTEMS OF FARM TENURE.}

Tा\% ststems of farm rental are found in the districts studied in the three States. The most common one is a share basis, whereby the orner furnishes the land and one-half the grass seed and pars onehalf the cost of thrashing and all his taxes and insurance. All grain crops are shared equalls, the tenant agreeing to deliver the landlord's share to the elerator or market. In a fer cases, especially in Indiana, where the grain is fed instead of sold, the owner furnishes half of the productive stock. There the landlord furnishes no stock and -ells his half of the grain the tenant may sell or feed his share. All hay or roughage is usually fed on the farm. In the grain districts very little hay is grown, the farmers using oat straw for feeding their horses.

\section{RELATION OF THE SYSTEM OF RENTAL TO THE TENANT'S INCOME.}

The kind of a lease the tenant secures has a bearing on his income. Table XXVII gives the labor incomes of tenants renting under both $-r$ stems. The tenants paring their rent in cash receired greater incomes in Indiana and Illinois, but less in Iowa. They have greater capital, although they are on smaller farms.

TABLE XXVII.-Relation of the system of rental to the tenant's income on $24 \%$ farms operated by tenants in Indiana, Illinois, and Iowa.

\begin{tabular}{|c|c|c|c|c|c|c|}
\hline \multirow{2}{*}{ State. } & \multicolumn{3}{|c|}{ Cash-rent system. } & \multicolumn{3}{|c|}{ Share-rent system. } \\
\hline & $\begin{array}{l}\text { Number } \\
\text { of farms. }\end{array}$ & $\begin{array}{l}\text { Tenant's } \\
\text { capital. }\end{array}$ & $\begin{array}{l}\text { Labor } \\
\text { income. }\end{array}$ & $\begin{array}{l}\text { Number } \\
\text { of farms. }\end{array}$ & $\begin{array}{l}\text { Tenant's } \\
\text { capital. }\end{array}$ & $\begin{array}{l}\text { Labor } \\
\text { income. }\end{array}$ \\
\hline 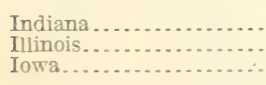 & $\begin{array}{l}14 \\
17 \\
27\end{array}$ & $\begin{array}{r}\$ 2,272 \\
3,118 \\
2,942\end{array}$ & $\begin{array}{r}\$ 864 \\
1,440 \\
689\end{array}$ & $\begin{array}{l}69 \\
54 \\
66\end{array}$ & $\begin{array}{r}\$ 1,654 \\
2,788 \\
2,555\end{array}$ & $\begin{array}{r}\$ 733 \\
1,044 \\
727\end{array}$ \\
\hline Total or average... & 58 & 2,777 & 998 & 189 & 2,332 & 835 \\
\hline
\end{tabular}

With the cash-rent srstem a tenant needs more capital than on the share basis. He has to bear all expenses and furnish nearly ererything for operating the place. He takes greater risks and in a poor rear stands a chance to lose hearily. If he has no surplucapital he may have to sacrifice some of his working equipment to pay the rent. 
The year for which the records in Iowa were taken was 20 per cent below normal, and this is the main reason the cash-rent tenants made less than those on a share basis. In a normal year they would undoubtedly have made from $\$ 800$ to $\$ 900$ in labor income.

When the landlord rents for cash he assumes very little responsibility and has no work to do in looking after the farm. He is therefore entitled to only a fair income on his investment and to no pay for general supervision.

RELATION OF THE SYSTEM OF RENTAL TO THE LANDLORD'S INCOME.

In Table XXVIII are given the incomes the landlords received on the same farms as shown in the preceding table.

TABle XXVIII.-Relation of the system of rental to the landlora's income on 247 farms operated by tenants in Indiana, Illinois, and Iowa.

\begin{tabular}{|c|c|c|c|c|c|c|}
\hline \multirow[b]{2}{*}{ State. } & \multicolumn{3}{|c|}{ Cash-rent system. } & \multicolumn{3}{|c|}{ Share-rent system. } \\
\hline & $\begin{array}{l}\text { Number } \\
\text { of farms. }\end{array}$ & $\begin{array}{l}\text { Land- } \\
\text { lord's } \\
\text { capital. }\end{array}$ & $\begin{array}{c}\text { Returns } \\
\text { on capital } \\
\text { invested. }\end{array}$ & $\begin{array}{l}\text { Number } \\
\text { of farms. }\end{array}$ & $\begin{array}{l}\text { Land- } \\
\text { lord's } \\
\text { capital. }\end{array}$ & $\begin{array}{l}\text { Returns } \\
\text { on capital } \\
\text { invested. }\end{array}$ \\
\hline $\begin{array}{l}\text { Indiana... } \\
\text { Illinois.... } \\
\text { Iowa...... }\end{array}$ & $\begin{array}{l}14 \\
17 \\
27\end{array}$ & $\begin{array}{r}\$ 14,968 \\
28,771 \\
19,114\end{array}$ & $\begin{array}{r}\text { Per cent. } \\
3.42 \\
2.50 \\
2.37\end{array}$ & $\begin{array}{l}69 \\
54 \\
66\end{array}$ & $\begin{array}{r}\$ 19,126 \\
38,906 \\
21,388 \\
\end{array}$ & $\begin{array}{r}\text { Per cent. } \\
3.55 \\
3.89 \\
3.49\end{array}$ \\
\hline Total or average....... & 58 & 20,951 & 2. 76 & 189 & 26,473 & 3.64 \\
\hline
\end{tabular}

Those who leased their farms on a cash basis received a much lower return than those on a share basis. This is to be expected, for the tenant took the risk and, as in Iowa, did not make as much as if he had rented the farm on shares.

The relative merits of the different systems of renting will not be discussed here. It is a subject of most vital importance and needs careful investigation. The present basis followed in the share system of rental has serious defects, which need adjusting for different regions according to the crops grown and the type of farming followed.

\section{COMPARISON OF CROP YIELDS ON FARMS OPERATED BY OWNERS WITH THOSE OPERATED BY TENANTS.}

It is the general belief that tenant farms have been robbed of their crop-producing power. The records for one year are by no means conclusive, yet when taken from adjoining farms in each district they are an indication of the results secured under both kinds of tenure. 
In Table XXIX is given the average yield for corn, oats, and wheat on the owner and tenant farms in the three States studied.

TABLE XXIX.-Comparison of crop yields on ouner and tenant farms in Indianu. Illinois, and Iorva.

\begin{tabular}{|c|c|c|c|c|c|c|}
\hline \multirow{3}{*}{ State. } & \multicolumn{6}{|c|}{ Yield per acre (bushels). } \\
\hline & \multicolumn{2}{|c|}{ Corn. } & \multicolumn{2}{|c|}{ Oats. } & \multicolumn{2}{|c|}{ Wheat. } \\
\hline & Owner. & Tenant. & Owner. & Tenant. & Owner. & Tenant. \\
\hline 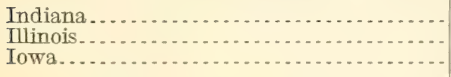 & $\begin{array}{l}52.5 \\
54.5 \\
37.9\end{array}$ & $\begin{array}{l}52.2 \\
52.2 \\
36.4\end{array}$ & $\begin{array}{l}47.8 \\
38.2 \\
34.9\end{array}$ & $\begin{array}{l}45.5 \\
39.7 \\
32.6\end{array}$ & $\begin{array}{l}19.5 \\
17.4 \\
19.7\end{array}$ & $\begin{array}{l}19.0 \\
15.4 \\
16.8\end{array}$ \\
\hline Average.... . & 48.3 & 46.9 & 40.3 & 39.3 & 18.9 & 17.1 \\
\hline
\end{tabular}

The farms operated by owners averaged about 2 per cent better yield than those operated by tenants. Tlse difference is small, much less than many persons imagine. Given equally productive soil, the tenant farmer will grow as good crops as the owner. The tenant has to work for what he gets, while the owner, often having large real estate holdings, does not need to hustle as much, because a return of eren 2 per cent on his capital is sufficient to give him a good living. The tenant farmer is unjustly criticized for conditions over which he has no control. He is compelled to agree to terms of lease whereby the landlord sells his half of the products regardless of the wishes of the tenant. With most of the farms rented on half shares the landlord and not the tenant is largely responsible for the wasteful system of farming.

\section{RELATION OF THE INCOME TO THE AGE OF THE FARMER.}

Under arerage conditions the farm is no place for the weak or for those unable to direct work. The man who intends to spend his working life in the country should start early, for success is not gained in a moment but by many years of persistent effort. It is true that some farmers have made small fortunes in a short time, but this is usually through a phenomenal rise in land ralues. Few men have become rich from the real profits of the land. Those who have done so usually needed a lifetime in which to work. Through skill in management and by hard labor a comfortable living and moderate profits may be expected. Those persons who are turning to the farm with the idea of reaping large incomes are doomed to severe disappointment.

The arerage age of the farm owners and the number of years they have been farming are given in Table XXX. 
TABLE XXX.-Relation of the farmer's income to his age and other factors on 273 farms operated by owners in Indiana, Illinois, and Iowa.

\begin{tabular}{|c|c|c|c|c|c|}
\hline Income. & Age. & $\begin{array}{l}\text { Number } \\
\text { of years } \\
\text { a tenant. }\end{array}$ & $\begin{array}{c}\text { Number } \\
\text { of years } \\
\text { an owner. }\end{array}$ & $\begin{array}{c}\text { Age } \\
\text { began } \\
\text { farming. }\end{array}$ & $\begin{array}{c}\text { Age } \\
\text { became } \\
\text { owner. }\end{array}$ \\
\hline $\begin{array}{l}\$ \$ \$ 1 \text { and more } \\
\$ 1 \text { to } \$ 400 \ldots \ldots \\
\$ 401 \text { to } \$ 800 \\
\$ 801 \text { to } \$ 1,500 \ldots \\
\$ 1,501 \text { and } 0 \text { over }\end{array}$ & $\begin{array}{l}52.7 \\
49.0 \\
48.8 \\
47.3 \\
48.0\end{array}$ & $\begin{array}{l}3.0 \\
2.0 \\
2.6 \\
4.6 \\
1.3\end{array}$ & $\begin{array}{l}21.3 \\
17.3 \\
18.3 \\
17.6 \\
20.6\end{array}$ & $\begin{array}{l}28.4 \\
29.7 \\
27.9 \\
25.1 \\
26.1\end{array}$ & $\begin{array}{l}31.4 \\
31.7 \\
30.5 \\
29.7 \\
27.4\end{array}$ \\
\hline A verage........ & 49.8 & 2.5 & 19.2 & 27.4 & 29.9 \\
\hline
\end{tabular}

Those making the poorest incomes were 28 years of age when they started farming and were past 30 when they became owners. On the average the oldest men are making the least profits.

Many of the farm owners in the North Central States whose records are included in this report started in farming as homesteaders, or else bought their places when land was cheap as compared to present prices. On the average these men rented land for $2 \frac{1}{2}$ years before becoming owners. This is a much shorter period than is required to-day. Land values in these regions are so high that many years of work as a tenant are necessary before sufficient funds can be acquired with which to buy a farm. The large amount of capital required and the long time necessary in which to earn this may have the effect of making more tenant farmers.

In Table XXXI are given the ages of the tenants and the time they began farming for themselves. No data showing how long these men worked as hired men before becoming tenants are available.

TABLE XXXI.-Relation of the income to the tenant's age and other factors on 247 farms operated by tenants in Indiana, Illinois, and Iowa.

\begin{tabular}{|c|c|c|c|c|c|}
\hline Income. & $\begin{array}{l}\text { Number } \\
\text { of farms. }\end{array}$ & Age. & $\begin{array}{l}\text { Number } \\
\text { of years } \\
\text { a tenant. }\end{array}$ & $\begin{array}{l}\text { Number } \\
\text { of years } \\
\text { on this } \\
\text { farm. }\end{array}$ & $\begin{array}{l}\text { Age } \\
\text { became } \\
\text { tenant. }\end{array}$ \\
\hline $\begin{array}{l}\$ 1 \text { and more } \\
\$ 1 \text { to } \$ 200 \\
\$ 201 \text { to } \$ 400 \\
\$ 401 \text { to } \$ 600 \\
\$ 601 \text { to } \$ 800 \ldots \ldots \\
\$ 801 \text { to } \$ 1,000 \ldots \ldots \\
\$ 1,001 \text { to } \$ 1,500 \ldots \\
\$ 1,501 \text { to } \$ 2,000 \ldots\end{array}$ & $\begin{array}{l}3 \\
25 \\
40 \\
41 \\
35 \\
33 \\
41 \\
12 \\
17\end{array}$ & $\begin{array}{l}44.7 \\
42.1 \\
38.3 \\
36.4 \\
36.6 \\
36.5 \\
35.1 \\
33.7 \\
35.3\end{array}$ & $\begin{array}{r}9.0 \\
12.8 \\
9.2 \\
8.6 \\
8.4 \\
9.0 \\
8.9 \\
6.8 \\
5.3\end{array}$ & $\begin{array}{l}3.7 \\
6.0 \\
4.4 \\
5.4 \\
4.9 \\
5.5 \\
4.9 \\
4.9 \\
4.5\end{array}$ & $\begin{array}{l}35.7 \\
29.3 \\
29.1 \\
27.8 \\
28.2 \\
27.5 \\
26.2 \\
26.9 \\
30.0\end{array}$ \\
\hline Total or average ...... & 247 & 37.0 & 8.9 & 5.1 & 28.9 \\
\hline
\end{tabular}

Results shown in other tables in this bulletin prove conclusively that the more capital a tenant has the greater his income; that is, the larger business he operates the larger is his pay. It might be expected, then, that the oldest tenants would be making the largest 
incomes. The results as given in Table XXXI show just the reverse; the oldest tenants make the lowest incomes. They have the least capital and farm the smallest areas. They are men, few in number, who are poor and inefficient farmers naturally, and who are not able to save enough money to buy a farm. Therefore, landlords with good farms will not rent their land to them, and they are compelled to take the least desirable farms in the neighborhood. The enterprising young men soon acquire sufficient funds to discontinue renting and become farm owners. The tenants of to-day seem to start in farming younger than did the owners who began 15 years ago.

The common saying that the tenant farmer moves from one farm to another every year is not supported by the data in Table XXXI. Five rears is the average period that the tenants had rented the farms of which the records were taken.

\section{RELATION OF THE EDUCATION OF THE FARMER TO HIS INCOME.}

Unquestionably one of the best things for a young man who intends to become a farmer is a good high-school education. Many farmers with very little schooling succeed, but these same men would do better if they had had the opportunity of further training. No one ever hears a farmer regret that he spent a part of his early life in school.

In Table XXXII the farmers are divided according to the extent of their education.

TABLE XXXII.-Relation of the ouner's or tenant's education to his income on farms in Indiana, Illinois, and Iowa.

\begin{tabular}{|c|c|c|c|c|c|c|c|c|c|c|}
\hline \multirow[b]{2}{*}{ Education. } & \multicolumn{5}{|c|}{ Operated by owners (273 farms). } & \multicolumn{5}{|c|}{ Operated by tenants ( 247 farms). } \\
\hline & $\begin{array}{l}\text { Num- } \\
\text { ber of } \\
\text { farms. }\end{array}$ & $\begin{array}{l}\text { Aver- } \\
\text { age size } \\
\text { (acres). }\end{array}$ & $\begin{array}{l}\text { Aver- } \\
\text { age cap- } \\
\text { ital. }\end{array}$ & $\begin{array}{c}\text { Aver- } \\
\text { age } \\
\text { labor } \\
\text { income. }\end{array}$ & $\begin{array}{l}\text { Aver- } \\
\text { age } \\
\text { age. }\end{array}$ & $\begin{array}{l}\text { Num- } \\
\text { ber of } \\
\text { farms. }\end{array}$ & $\begin{array}{l}\text { Aver- } \\
\text { age size } \\
\text { (acres). }\end{array}$ & $\begin{array}{l}\text { Aver- } \\
\text { age cap- } \\
\text { ital. }\end{array}$ & $\begin{array}{c}\text { Aver- } \\
\text { age } \\
\text { labor } \\
\text { income. }\end{array}$ & $\begin{array}{l}\text { Aver- } \\
\text { age } \\
\text { age. }\end{array}$ \\
\hline $\begin{array}{l}\text { None at school ........ } \\
\text { Common school . ...... } \\
\text { High school ........... } \\
\text { College, etc.......... }\end{array}$ & $\begin{array}{r}4 \\
214 \\
46 \\
9\end{array}$ & \begin{tabular}{r|}
91 \\
165 \\
206 \\
240
\end{tabular} & $\begin{array}{r}\$ 15,039 \\
27,494 \\
37,725 \\
42,781\end{array}$ & $\begin{array}{r}-\$ 586 \\
301 \\
651 \\
796\end{array}$ & $\begin{array}{l}55 \\
51 \\
46 \\
53\end{array}$ & $\begin{array}{r}4 \\
186 \\
51 \\
6\end{array}$ & $\begin{array}{l}118 \\
167 \\
190 \\
294\end{array}$ & $\begin{array}{r}\$ 1,650 \\
2,200 \\
3,203 \\
3,351\end{array}$ & $\begin{array}{r}\$ 680 \\
742 \\
1,268 \\
1,721\end{array}$ & $\begin{array}{l}40 \\
38 \\
33 \\
41\end{array}$ \\
\hline Total or average & 273 & 178 & 30,606 & 408 & 49.8 & 247 & 172 & 2,431 & 870 & 37 \\
\hline
\end{tabular}

There were only eight men, four owners and four tenants, who never had a school training. Of the owners and tenants 77 per cent attended a common or district school. About 18 per cent attended a high school. and one out of every 35 went to college or to some institution of similar grade.

On the whole the tenants had received more education than the owners. 2?) per cent of them haring more than a district-school education, while only 20 per cent of the owners had such training. 
Those men having the best training made the largest incomes, although they were materially helped in doing this by much larger farms and greater capital.

To determine the real influence of education, the tenant farmers having the same training were divided according to their capital (Table XXXIII).

TABLE XXXIII.-Relation of education to profits of tenants with equal capital.

\begin{tabular}{|c|c|c|c|c|c|c|c|c|}
\hline \multirow{3}{*}{ Units of comparison. } & \multicolumn{8}{|c|}{ Capital and training. } \\
\hline & \multicolumn{2}{|c|}{$\$ 1,000$ and less. } & \multicolumn{2}{|c|}{$\$ 1,001$ to $\$ 2,000$. } & \multicolumn{2}{|c|}{$\$ 2,001$ to $\$ 3,000$. } & \multicolumn{2}{|c|}{ Over $\$ 3,000$. } \\
\hline & $\begin{array}{l}\text { Common } \\
\text { school. }\end{array}$ & $\begin{array}{c}\text { High } \\
\text { school. }\end{array}$ & $\begin{array}{l}\text { Common } \\
\text { school. }\end{array}$ & $\begin{array}{l}\text { High } \\
\text { school. }\end{array}$ & $\begin{array}{l}\text { Common } \\
\text { school. }\end{array}$ & $\begin{array}{l}\text { High } \\
\text { school. }\end{array}$ & $\begin{array}{l}\text { Common } \\
\text { school. }\end{array}$ & $\begin{array}{c}\text { High } \\
\text { school. }\end{array}$ \\
\hline $\begin{array}{l}\text { Number of farms..... } \\
\text { Average size....acres.. } \\
\text { Average age of farmer. }\end{array}$ & $\begin{array}{l}23 \\
69 \\
36.4\end{array}$ & $\begin{array}{c}3 \\
109 \\
29.3\end{array}$ & $\begin{array}{c}73 \\
138 \\
36.9\end{array}$ & $\begin{array}{c}19 \\
123 \\
31.1\end{array}$ & $\begin{array}{c}54 \\
184 \\
39.8\end{array}$ & $\begin{array}{c}12 \\
165 \\
28.3\end{array}$ & $\begin{array}{l}40 \\
251 \\
39.5\end{array}$ & $\begin{array}{l}23 \\
266 \\
36.8\end{array}$ \\
\hline $\begin{array}{l}\text { A verage capital ...... } \\
\text { A verage labor income }\end{array}$ & $\begin{array}{r}\$ 686 \\
318\end{array}$ & $\begin{array}{r}\$ 730 \\
259\end{array}$ & $\begin{array}{r}\$ 1,517 \\
561\end{array}$ & $\begin{array}{r}\$ 1,549 \\
659\end{array}$ & $\begin{array}{r}\$ 2,427 \\
864\end{array}$ & $\begin{array}{r}\$ 2,513 \\
866\end{array}$ & $\begin{array}{r}\$ 4,023 \\
1,086\end{array}$ & $\begin{array}{r}\$ 5,095 \\
2,087\end{array}$ \\
\hline
\end{tabular}

The difference is in favor of the high-school men, especially in the group of those having over $\$ 3,000$ capital. In this case they made nearly double the average income.

Considering that the farm boys of to-day will be the farmers of to-morrow, altogether too little attention is given to their training. Farming is a business the same as any other industry, and until our schools teach some of the fundamental principles governing profitable farming the farm boy is likely to seek work elsewhere. Many boys leave the farm because they see no future in it. Another important reason is the lack of profitable work at home. A moderatesized farm is necessary to give employment to the farmer and his sons. The small farm does not provide work; hence, the boys must find employment elsewhere. Let them fully understand how farm profits and losses are made and there will be an incentive to remain. First make our farms profitable, and the question of keeping the boys there will solve itself.

\section{FARMING AS A BUSINESS.}

By studving a sufficient number of farms in a region one may learn how the more successful farms differ from the less successful. So far, this discussion has dealt only with an analysis of the farm business. From this study of profitable and unprofitable farms certain important principles governing farm organization are clearly brought out. These fundamentals are as follows: (1) Size of business, (2) quality of business, (3) diversity of business, and (4) adaptability of the type of farming. 
Size of the farm business.-No one expects a small grocery store which has only a few customers a day to be a great financial success. The total amount of business is insufficient to earn the operator a substantial income. Exactly the same is true with the small farm. The volume of business is limited by the area in crops and the capital inrested. The small farm furnishes a home as well as much of the produce consumed by the family. If it were not for these factors the men on the small area would hardly be able to live.

Wages are a reward for labor, and if a farm does not provide work the pay must be correspondingly small. The family-size farm, which in the corn belt should be abore 100 acres, is unquestionably a more efficient unit than an area of 40 acres or less. Crops can be grown cheaper, labor will be better paid, and the farmer and his family will enjoy more of the benefits of modern civilization.

Quality of the farm business.-The farmer may have sufficient area and grow the right kind of crops, yet not be successful, owing to the poor quality of his entire business. Poor crops that do not pay the cost of production, and the feeding of these to unproductive live stock are common causes of failure. This characteristic of unsuccessful farming attracts much public attention. Such farms are unprofitable largely through ignorance or indifference on the part of the operator. Under good management they can generally be made successful.

Diversity of the farm business.--Improper organization of a large farm limits its possibilities, just as area limits the small farm. Single crops or single live-stock enterprises seldom utilize farm labor to its maximum. By haring sereral crops there is not only better distribution of labor, but the chances of total loss from crop failures are lessened. Fortunately, corn, oats, and wheat utilize the farmer's time pretty thoroughly through the growing season. In some parts of this country certain crops that need labor only a part of the year may be so profitable that the farmer can afford to be idle the rest of the year. However, these are the exceptions. Most crops are not profitable enough to permit any such practice. Idle horses and machinery are nearly as expensive as idle men. (See fig. 10.) If the working equipment can all be kept busy on paying enterprises, success is almost assured.

Adaptability of the type of farming.-Equally important in the selection of enterprises to permit the maximum use of labor is the consideration of the profitableness of each. Dairy corrs and cash crops may utilize all of the farmer's time, but in certain regions, possibly, dairy cattle under the best management could hardly be made to pay a profit. Markets and other conditions have to be carefully considered in choosing the enterprises which are to constitute the main sources of income. Fitting the right crop to the soil and 
selling it to the proper market or feeding it to the right kind of live stock are important factors. Following such types of farming as are unsuited to the region is often a cause of unprofitable agriculture in some of the older settled States.

The wide fluctuation in prices of certain crops makes it extremely difficult for a farmer to choose a definite rotation. One year they will be such as to give handsome profits on certain crops, and the next year they may be insufficient to pay the cost of production. The question confronting the average farmer is not so much one of production as it is of marketing. Most farmers are able to grow a sufficient quantity of crops to give them a very comfortable living if they are assured of reasonable prices for their products. However, under present conditions the farmer has to take big chances with nearly all

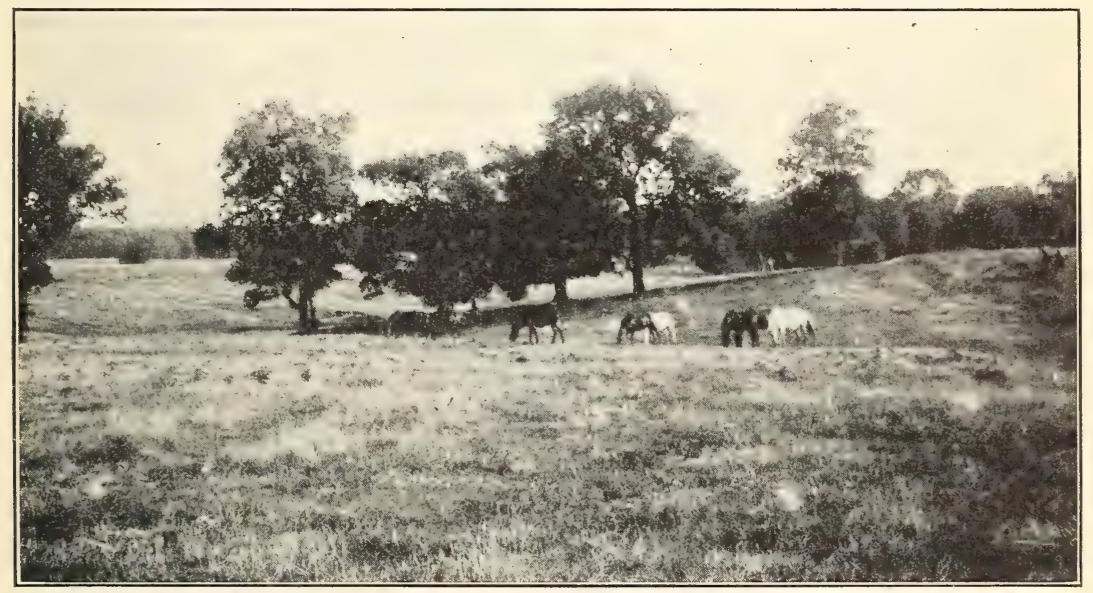

Fig. 10.-Farm work horses and mules in pasture during the month of August, illustrating a practice which is common in many sections.

of his crops. If he is so unfortunate as to have a combination of crops every one of which is low in price in some particular year, severe losses will be the result. Potatoes, apples, peaches, onions, and cabbage are good illustrations of the crops that fluctuate widely in price from year to year.

The essential characteristics of the more successful farms are a sufficient area and a proper organization of well-selected farm enterprises to permit the maximum use of men, horses, and machinery.

\section{SUMMARY.}

The aim of the farm-management survey is to determine the factors governing the profitableness of farming as a business.

The results from the three districts selected in Indiana, Illinois, and Iowa indicate what may be expected from the utilization of 
high-priced land under an expansive system of agriculture. In the region studied the owners made good profits. The average labor income of the farm owners was $\$ 408$ and of the tenants $\$ 870$. In addition, the operators had a house to live in and those products which the farm furnished toward their living.

The landlords, on the average, received 3.5 per cent on their investments. The size of their investments had no appreciable bearing on the rate of income.

Assuming that the year in which this study was made was a normal one, a labor income of $\$ 870$ to the operator, whether owner or tenant, and a return of 3.5 per cent on the capital invested may be expected.

The tenant's income is in direct proportion to his capital and the size of the farm he operates. Men owning small farms often materially increase their incomes by renting additional land. This affords a better utilization of their equipment without much increase in capital.

The tenant's income is in proportion to the risk he assumes. On the cash-rent basis his income is greater in a good year and less in a poor year than when he rents on the share basis.

The farmers making the lowest labor incomes are on big farms, but fail through inefficient management. Poor crops, low prices for products sold, poor stock, failure to work, and unused capital are the main causes contributing to their failure.

Modern machinery, with the use of more horses and fewer men, has made the farm of less than 100 acres an inefficient unit. Further readjustments in area will occur, which will tend to lessen the number of persons needed and at the same time increase the net production of the farm.

The system of agriculture found in the corn-growing States is an excellent example of the expansive type of farming developed on the basis of the farm work horse as the motive power. This system is in direct contrast to the intensive type found in some of the countries of southern Europe, where the man and not the horse furnishes the labor. The American type needs large areas and is based on the maximum product per man. The European type requires a small area and is based on the maximum product per acre of land.

In the corn-belt States the family-size farm is the most desirable. It provides work for the farmer and his sons and permits the best use of men, horses, and machinery. If the small farm has a place it must be near a city and should be highly diversified in its organization. 
DDITIONAL COPIES of this publication $A$ may be procured from the SUPERINTENDENT OF Documents, Government Printing Office, Washington, D. C., at 10 cents per copy

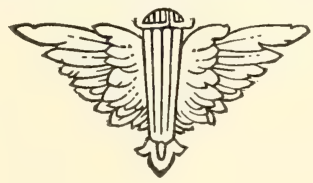






